\title{
What Explains Fertility? Evidence from Italian Pension Reforms
}

\author{
FRANCESCO C. BILLARI \\ VINCENZO GALASSO
}

\section{CESIFO WORKING PAPER No. 2646 \\ CATEgory 3: Social Protection \\ MAY 2009}

Presented at CESifo Area Conference on Employment And Social Protection, May 2009

\footnotetext{
An electronic version of the paper may be downloaded

- from the SSRN website: www.SSRN.com

- from the RePEc website: - from the CESifo website: 


\title{
What Explains Fertility? Evidence from Italian Pension Reforms
}

\begin{abstract}
Why do people have kids in developed societies? We propose an empirical test of two alternative theories - children as "consumption" vs. "investment" good. We use as a natural experiment the Italian pension reforms of the 90s that introduced a clear discontinuity in the treatment across workers. This policy experiment is particularly well suited, since the "consumption" motive predicts lower future pensions to reduce fertility, while the "old-age security" to increase it. Our empirical analysis identifies a clear and robust positive effect of less generous future pensions on post-reform fertility. These findings are consistent with "oldage security" even for contemporary fertility.
\end{abstract}

JEL Code: H55, J13, D64.

Keywords: old-age security, public pension systems, fertility, altruism.

\author{
Francesco C. Billari \\ IGIER \\ Bocconi University \\ Via Roentgen 1 \\ 20136 Milan \\ Italy \\ francesco.billari@unibocconi.it
}

\author{
Vincenzo Galasso \\ Bocconi University \\ Department of Economics \\ Via Roentgen 1 \\ 20136 Milan \\ Italy \\ vincenzo.galasso@unibocconi.it
}

\section{May 2009}

We thank Alberto Alesina, Michele Boldrin, John Bongaarts, Flavio Cunha, Frank Furstenberg, Tullio Jappelli, Dirk Krueger, Tommaso Nannicini, Michele Pellizzari, Adrian Peralta-Alva, Sam Preston, Paola Profeta, Hans Werner Sinn, and participants at the 2008 Annual Meetings of the Population Association of America, New Orleans, the 2008 Annual Meetings of the IIPF, Maastricht, the 2008 Annual Meetings of the European Economic Association, Milan and at seminars at Università Bocconi, University of Pennsylvania, Università di Salerno, Università di Venezia and FEDEA for useful comments. All remaining errors are ours. 


\section{Introduction}

Couples in industrialized societies have much fewer kids than they used to. In 195055 , only $0.4 \%$ of the world's population lived in areas in which the total fertility rate (i.e., the average number of children per couple) was below the replacement level of 2.1 kids. This figure has risen to $43.3 \%$ in $2005-10$, and is expected to reach $79.9 \%$ in 2045-50 (United Nations, 2007). Fertility decline had long been predicted as a longlasting phenomenon. Yet, observing some countries with below-replacement fertility came as a surprise. Not any longer. In Southern and Central-Eastern Europe, and later in Eastern Asia, fertility has indeed fallen to levels that are close to one child per couple: the so called "lowest-low fertility" (Kohler et al., 2002).

The paper addresses this crucial issue: why are we not having as many kids as we used to? Or, even more fundamentally, why do we have kids at all? In particular, why do parents decide to have kids in contemporary developed countries? We review the two main motives for childbearing that exist in the literature, and assess their empirical validity using a unique natural experiment. The family economics approach, systematized by Becker and Barro (1988) and Barro and Becker (1989), suggests that parents are altruistic towards their kids. Individuals obtain directly pleasure from having and raising children, and from their well-being. Kids thus resemble a "consumption" good in the utility function of their parents, who will optimally decide to share their resources between their own consumption and the consumption of their offsprings. Genetic endowments influence the propensity to have children (see, e.g., Kohler et al., 1999; Rodgers et al., 2001). The "old-age security" motive focuses instead on intergenerational flows within the family and considers children as an "investment" good. In line with early work by Leibenstein (1957), Neher (1971), Caldwell (1978 and 1982), Cain (1981), and more recently Boldrin and Jones (2002) argue that parents may decide to have children because they expect to receive back a (monetary or in-kind) transfer from them in their old age. In this case, altruism runs from the kids towards their parents. This "old-age security" motive would be particularly relevant in societies in which family ties are more binding and where there are no alternative reliable savings instruments.

In this paper, we provide a test of these two alternative theories of fertility in 
an advanced, post-demographic transition society, characterized by low fertility and strong family ties: Italy. We analyze the effect on fertility choices of two recent Italian pension reforms (the so-called "Amato" reform in 1992 and the "Dini" reform in 1995), which suddenly - and substantially - decreased pension prospects for a large group of individuals. These pension reforms represent a unique natural experiment, which allows to address the relevance of the standard family economics approach (or kids as a consumption good) versus the old-age security motive (or kids as an investment good). The design of the reform introduced a clear discontinuity in the size of future pension benefits across workers. Pension benefits of the individuals with 15 years of contributions or more at the end of 1992 were not modified, while pension entitlements were largely reduced for all other workers on a pro-quota basis, which took into account their contributory history. A similar discontinuity, affecting exactly the same cohorts of workers, was then introduced by the Dini reform in 1995. The magnitude of the discontinuity is sizeable. Due to the reforms, a oneyear difference in the length of contributions in 1992 (14 vs. 15 years) for two individuals with otherwise the same characteristics commanded a difference in the pension replacement rate (measured as the ratio between the pension benefit and the last wage prior to retirement) of 15 points - that is, a replacement rate of $80 \%$ for the individual with 15 years in contributions in 1992 versus $65 \%$ for the other individual.

This policy-induced natural experiment is particularly well suited to differentiate between the two theories of childbearing, which predict opposite effects of a reduction in the future pension benefits on the fertility. The traditional "consumption" motive suggests in fact that a reduction in the future entitlements reduces life-time income and should hence lead to a reduction in the parents' own consumption and fertility - provided that kids are "normal" goods. In their original contribution, ${ }^{1}$ Becker and Barro (1988) argued in fact that, in a dynamically efficient economy (i.e., when the net present value from social security for a young individual is negative), an increase in social security spending is analogous to an increase in the cost of having kids, and should hence lead to lower fertility. The reduction in future pension

\footnotetext{
${ }^{1}$ Their model, however, was not built to address social security issues, since individuals were assumed to live only in youth and in working age.
} 
benefits experienced by the individuals who were affected by the Italian pension reforms decreases the net present value of social security and is thus equivalent to an increase in the cost of having kids. Fertility should hence drop. The "old-age security" motive instead leads to the opposite prediction (see Boldrin, De Nardi, and Jones, 2005). The reduction in old-age resources for the affected group, due to the lower expected pension benefit, should induce these agents to increase their financial assets and their fertility in order to support their old-age consumption ${ }^{2}$.

Our test of these two fertility motives is staged in Italy - a country characterized by strong family ties (Reher, 1998; Dalla Zuanna, 2001; Giuliano, 2007). In fact, according to a measure of the strength of family ties constructed by Alesina and Giuliano (2007), Italy ranks third among the OECD countries, after Mexico and Poland and followed closely by the US and Spain, while Germany and the Scandinavian countries have the weakest family ties ${ }^{3}$. The results of our empirical analysis on the effect of the Italian pension reforms emphasize the relevance of the "old-age security" motive for contemporary fertility. We find a clear positive effect of the pension reform on the average number of post-reform children and on the probability of having a kid after the reform. Sensitivity analysis confirms the robustness of these findings. Our findings complement previous results by Attanasio and Brugiavini (2002) and Bottazzi, Jappelli and Padula (2007), who find an increase in savings among the individuals affected by the (Amato) pension reform - particularly among those who are better informed about the costs of the reform process. Interestingly, all these empirical findings are consistent with the existence of a strong old-age security motive in the contemporaneous Italian society. The underlying belief that support and insurance can be found within the family is also in line with Bentolila

\footnotetext{
${ }^{2}$ Clearly, were both motive to be equally present, these changes in pension benefits would have little or no effect on fertility.

${ }^{3}$ Alesina and Giuliano (2007) construct a measure of the strength of family ties by considering individual answers to three questions on the importance of the family carried out in different waves of the World Value Survey. The first question asks how important the family is in one person's life; the second question asks whether the respondent agrees with one of these two statements: (i) regardless of what the qualities and faults of one's parents are, one must always love and respect them; (ii) one does not have the duty to respect and love parents who have not earned it; and the third question asks whether the respondent agrees with one of these two statements: (i) it is the parents' duty to do their best for their children even at the expense of their own well being; (ii) parents have a life of their own and should not be asked to sacrifice their own well being for the sake of their children.
} 
and Ichino (2008) findings that in Italy and Spain - and to a large extent also in the US, yet not in Britain - families provide a strong support, e.g., through monetary transfers, to the male household head who becomes unemployed.

Our results have relevant implications. First, they help to clarify the existence of a causal link running from public pension systems to fertility decisions: lower pension benefits increase fertility. Along these lines, our analysis might contribute to explaining, at least in part, recent fertility trends, including the (mild) reversal towards high fertility which has been observed in Italy since the mid-1990s. Moreover, it also suggests that in many developed societies, at least where family ties matter, the strong decreasing trend in fertility may be partially due to the large rise in pension spending. Second, our empirical findings fail to support the traditional "consumption" motive, which has become the workhorse model of fertility choice in a recent literature on demographic transition and economic growth, or female labor force participation. One should be aware of this shortcoming, in particular when drawing policy implications on how to revert this demographic trend ${ }^{4}$ (e.g., through public intervention aimed at the provision of services, such as publicly funded child-care, or at tax reliefs or other monetary incentives), base on this "traditional" fertility model, especially for countries that feature a "traditional" family structure.

The paper proceeds as follows. Section 2 discusses the related literature. Section 3 briefly describes the Italian pension reforms of the 1990s, underlining the discontinuity embedded in their design. Section 4 presents two models, which capture the effects of a pension benefit reduction on the fertility under the two different motivations - kids as "consumption" or "investment" good. Section 5 presents the data that we use and discusses our identification strategy. The empirical results and the sensitivity analysis are in section 6 . Section 7 discusses the results and concludes.

\footnotetext{
${ }^{4}$ A large debate has developed on this issue, especially since individuals in most of these countries have repeatedly expressed their willingness to have more children than they actually do (Goldstein et al., 2003).
} 


\section{Related Literature}

Since the seminal papers by Becker and Barro (1988) and Barro and Becker (1989), a large literature has emerged that analyzes demographic phenomena based on the "consumption" motive for fertility. The initial formulation of this theory has been enriched with the introduction of several additional channels that may affect fertility, such as for instance human capital (e.g., Becker, Murphy and Tamura, 1990), child mortality (e.g., Mateos-Planas, 2002, and Doepke, 2005), and health capital (e.g., Manuelli and Seshadri, 2009). Recently, Jones and Schoonbroodt (2007) and Jones, Schoonbroodt and Tertilt (2008) pointed out that the traditional formulation of this theory is unable to reproduce the negative relation between fertility and income, and endorsed an alternative interpretation in which the number of children and their utility are not complements (as implicitly assumed in Becker and Barro, 1998), but rather substitutes. This new formulation seems more promising in accounting for the negative - cross section and time series - relation between fertility and income. Along these lines, Manuelli and Seshadri (2009) extend Barro-Becker framework to incorporate the decisions of accumulating human and health capital. Their richer model is able to produce a negative correlation between total factor productivity growth (and thus income) and fertility, and to account for part of the observed cross-country differences in fertility.

An alternative theory of fertility, based on the "old-age security" motive, which was initially introduced by Leibenstein (1957), has recently been formalized in a general equilibrium framework by Boldrin and Jones (2002), who analyze the effects of a reduction in infant mortality on fertility. Boldrin, De Nardi and Jones (2005) subsequently used a calibrated version of the Boldrin and Jones (2002) model to quantify the effect of the rise in pension spending on fertility trends. According to their calibrated model, around $50 \%$ of the long-term drop in fertility in the US is accounted for by the pension system. The same quantitative experiment is also carried out using a general equilibrium version of the Barro and Becker (1988) model, which however delivers the opposite effect. The "consumption" good model predicts indeed a mild raise in fertility following an increase in pension spending. Manuelli and Seshadri (2009) model with human and health capital is however able to restore 
the original Becker and Barro (1988) prediction that - in a dynamically inefficient economy - higher social security spending leads to lower fertility.

The link between social security and fertility has been extensively explored in the literature, with several contributions implicitly endorsing the importance of the "old-age security" motive. For instance, Sinn (2004) argues in favor of public pension system since they provide an insurance against the risk of not having children, or of having ungrateful children, who are unwilling (or unable) to take care of their old parents. Yet, as also suggested by Sinn (2004) model, a drawback of public pension systems is that, even in households with grateful children, they tend to reduce kids-to-parents transfers. Parents have an incentive to "free ride" on the social security contributions paid by other people's children. As a result, fertility falls (see Cigno, 1993). Policy suggestions to overcome this free riding problem are for instance in van Groezen, Leers and Meijdam (2000, 2003), and Fenge and Meier (2004). Empirical studies on the negative correlation between fertility and various measures of the size or the generosity of the public pension system include Swidler (1983), Cigno and Rosati (1992, 1996) and Galasso, Gatti and Profeta (2009).

Some empirical contributions have provided evidence in favor of the old-age security motive in contemporary societies. Kagitcibasi (1982) argued that old-age security was not a reason for fertility in societies such as Germany and the U.S. during the 1970s, despite this motive had been cited as "somewhat important" or "very important" by 32 percent of married German women and 27 percent of married U.S. women during interviews. Rendall and Bahchieva (1998) on the other hand, point out to the potentially high relevance of old-age security motives in contemporary developed societies, by providing an extensive documentation of the relevance of children for providing support to their elderly parents in contemporary U.S: 11 percent of all unmarried elderly in the U.S. live above poverty because of co-residence with adult children, and observed poverty rates would double in absence of such co-residence. Co-residence is therefore a crucial way to transfer income from adult children to their elderly parents also in the US, a country that has almost the same strength of family ties as Italy, according to the measure of Alesina and Giuliano (2007). Recent analyses of comparative data on support towards parents show that 
in countries with strong family ties help to parents is more widespread (Kalmijn and Saraceno, 2008). In a 1998 "Eurobarometer" survey, 76 percent of adult Italians state that in the future working adults may have to look after their parents more than they do now, 52 percent that a needy elderly parent should co-reside with a child, 23 percent state that children should have the main economic responsibility when elderly parents are in need (Kalmijn and Saraceno, 2008). Despite its relevance, systematic empirical evidence of the existence of the old-age security motive for fertility in contemporary developed societies is lacking up to date.

A recent and growing literature on demographic transition and economic growth (see Galor, 2005, for a review) appears to have taken a stand on the off-the-shelves fertility choice model to use. In fact, the "consumption" motive introduced by Becker and Barro (1988) has become the workhorse model for fertility decisions, either in its full-fledged version with parents-to-kids altruistic preferences (see Doepke, 2005) or in more reduced form versions (see for instance Galor and Weil, 2000, Galor and Moav, 2002, de la Croix and Doepke, 2003, and Greenwood, Seshadri and Vanderbrouche, 2005).

Finally, a small and recent empirical literature has exploited the peculiar discontinuity and the related natural experiment created by the Italian (Amato and Dini) pension reforms. These contributions include Attanasio and Brugiavini (2002), who estimate the effect of the reduction in pension benefits on savings, Bottazzi, Jappelli and Padula (2007), who analyze the impact on retirement decisions and Manacorda and Moretti (2006), who concentrate on the decision of young children to leave the parental home.

\section{The "Amato" and "Dini" Pension Reforms}

By the end of the 1980s, Italian social security spending was among the largest in the world. Pension spending had increased from less than 1\% of GDP in 1951, to almost $15 \%$ in 1992, in the eve of the Amato reform, while the share of elderly (60 years old or more) in the population had increased from $12 \%$ to $25 \%$. The aging process, which had already increased the number of individuals entitled to a pension, was partially accountable for the upward trend in pension expenditure, which was 
also due to an increase in the generosity of the pension benefits. Faced with the expectations of further aging and crisis, the Italian system was largely re-designed during the nineties ${ }^{5}$ - mainly by the Amato reform in 1992 and the Dini reform in 1995.

The Amato reform introduced a gradual tightening, over a ten-year period, of the eligibility requirements. Retirement age was increased to 60 years for women and to 65 years for men, and the minimum contribution period for pension eligibility was extended to 20 years. Moreover, the minimum contribution period for being eligible to an early retirement pension was extended to 35 years for all (private and public) workers. The reference wage in the pension benefit formula moved from the average wage over the last five years prior to retirement to the average wage during the entire working carrier, with past earnings capitalized at the cost of living index plus $1 \%$ per year. Pension benefit indexation moved from nominal wages to prices.

Yet, most of these reform measures did not apply to some generations of workers. In particular, the benefit calculations for the workers with at least 15 years of contributions at the end of 1992 were untouched, and access to early retirement remained virtually the same. For workers with fewer years of seniority, instead, the new rules were applied pro-quota. Only to individuals who entered the labor market in 1993 were the new rules entirely applied. Hence, this reform design gave raise to large differences in the reduction of social security wealth across workers with different seniorities, as well as across public and private employees, who initially enjoyed different treatments.

To better understand this discontinuity, let us consider two workers ${ }^{6}$ in the private sector with a high-school degree, who entered the labor market at the same age (20), and have had the same labor earning profile. However, they were born one year apart and thus had different years of contributions at the end of 1992 . While Mr. Old is one year older - he was born in 1957 - and already had 15 years of contributions, Mr. Middle (born in 1958) only had 14. Suppose that they will both retire at age 60 upon reaching forty years of contributions. Mr. Old will then retire in 2017 and his pension benefits will entirely be calculated according to the

\footnotetext{
${ }^{5}$ See Brugiavini and Galasso (2004) for a detailed description of the reform measures.

${ }^{6}$ For simplicity and for consistence with the empirical part, we refer to male workers.
} 
pre-reform rules. His replacement rate - that is, the share of his labor income at age 59 replaced by the pension benefit - would be around $80 \%$. Mr. Middle will instead retire a year later, in 2018. His pension benefits will be calculated for almost two thirds (26/40) according to the new rules, and only for the remaining part (14/40) according to the pre-Amato reform scheme. For Mr. Middle, the replacement rate would only be around $70 \%$. This amounts to a large discontinuity: the pension treatment of individuals who at the end of 1992 differed in one year of contribution only was set to be noticeably large.

Attanasio and Brugiavini (2002) estimated that, in the private sector, the drop in social security wealth due to the Amato reform was equal to $27.6 \%$ for workers born after 1957 and to $17 \%$ for those born between 1945 and 1957. This reduction was even larger among the public employees: respectively $32.1 \%$ for the younger workers and $27.1 \%$ for the $1945-1957$ generation.

In 1995, the Dini reform completely redesigned the architecture of the Italian social security system, shifting from defined benefit to notional defined contribution. Eligibility criteria were also largely revised. Seniority pensions, whose eligibility was exclusively based on reaching a minimum contribution period, were abolished. Under the private employees' scheme, the minimum number of years of contribution to be eligible for a pension was reduced to 5 years only; however, only individuals aged between 57 and 65 years are entitled to a pension. As for the Amato reform, these measures were introduced along a transition path that left those workers with at least 18 years of contributions at the end of 1995 unaffected, while being applied pro-quota for the less senior, and entirely only for the workers entering the labor market in 1996. Interestingly, those workers who escaped the retrenchment of the Dini reform had already been unaffected by the Amato reform. Returning to our example, while Mr. Old maintained his (expected) replacement rate of $80 \%$, Mr. Middle only had 17 years of contributions in 1995 and thus had to face a further reduction in his (expected) pension benefits. Leaving his retirement age unchanged at 60 years, his replacement rate would in fact drop to around $65 \%$.

Bottazzi et al. (2007) assessed the differential impact of the Amato and Dini reforms on three classes of workers: those with a seniority of 18 years in 1995 (and 
15 in 1992), those with a lower seniority and those who entered the labor market after 1995. The differences in the reduction of their replacement rate - as measured by the ratio of pension benefit to the average wage in the last five years prior to retirement - are quite large. Among the private employees retiring at age 60 , the replacement rate is reduced by 1 point (from $67.3 \%$ to $66.3 \%$ ) for the senior workers, by 9.1 points (from $67.3 \%$ to $58.2 \%$ ) for the less senior and by 12.4 points for the young. The impact is larger among public sector employees, with a drop of 5.1 points among the senior, of 20.6 among the less senior and of 26.7 among the young.

These major changes did not come unperceived, nor was the differential impact of the reform across generation of workers underplayed. Quite the opposite. Besides the strikes that broke out in 1992 and 1994, and the debate that took place in the press, estimates by Bottazzi et al (2007) suggest that private employees were well aware of the magnitude of the reform and of its differential impact according to the years of contributions. In particular, less senior private employees expecting to retire at age 60 quite accurately forecasted their replacement rate to be reduced by 8.4 points, whereas senior workers overestimated the drop in their replacement rate $(4.3$ points). The relevance of these reforms and their differential effect is also evident in the workers intention to postpone retirement after the reform. Consistently with this differential effect, Bottazzi et al. (2007) estimate the increase in the expected retirement age to be larger for middle aged (born after 1957) than for more senior workers.

\section{Two Models of Fertility Decisions}

In this section, we introduce two overlapping generations models, which characterize the households' fertility decisions under the "consumption" good motive and under the "old-age security" motive. They will provide a useful background for subsequent empirical analyses, by showing how the Italian pension reforms described in section 3 may affect fertility decisions under these two different motives for childbearing.

Fertility decisions are taken at the household level. For each household, we consider a representative altruistic individual (for simplicity a man), who cares about his youth and old-age consumption, but also (i) about the wellbeing of his parents, 
in the "old-age security" model; and (ii) about the utility of his offsprings, in the "kids as consumption good" $\operatorname{model}^{7}$.

During the first period of their life, individuals work, and earn a wage $w_{t}$, on which they pay contributions, $\tau_{t} \in[0,1]$, that are used to finance a PAYG pension system, and a proportional tax, $\sigma_{t} \in[0,1]$, which provides general revenues. Their net labor income is summarized by $y_{t}=w_{t}\left(1-\tau_{t}\right)\left(1-\sigma_{t}\right)$. They may also receive a bequest, $b_{t}$, from their (altruistic) parents. Their total amount of resources when young are used to consume, $C_{t}^{t}$, to save, $s_{t}$, to raise $f_{t}$ kids, and - if kids-to-parents altruism is present - to transfer resources to their parents, $d_{t}$. Bringing up a child has a fixed marginal cost, $\gamma$. In the second period of their life, agents do not work, but may obtain resources from three sources: private savings, transfers from their kids and public pensions. Their total income is divided between old age consumption, $C_{t+1}^{t}$, and (if altruistic) bequest to their kids, $b_{t+1}$.

The budget constraints in youth and old age for an agent born at time $t$ are thus respectively as follows:

$$
\begin{gathered}
C_{t}^{t}+\gamma f_{t}+s_{t}+d_{t}=w_{t}\left(1-\tau_{t}\right)\left(1-\sigma_{t}\right)+b_{t}=y_{t}+b_{t} \\
C_{t+1}^{t}+b_{t+1} f_{t}=s_{t} R_{t+1}+d_{t+1} f_{t}+P_{t+1}
\end{gathered}
$$

Notice that superscripts denote the time of birth of the individual, and time subscripts denote time of action. Hence, $C_{t}^{t}$ and $C_{t+1}^{t}$ represent respectively the consumption in youth and in old age for an individual born at time $t$, and $f_{t}$ indicates fertility for an individual at time $t$. Moreover, $R_{t+1}$ is the interest factor on the savings, and $P_{t+1}$ represents the pension transfer at time $t+1$.

Throughout his life, each individual chooses the amount of savings, $s_{t}$, fertility, $f_{t}$, and the amount of the transfer - either $d_{t}$ or $b_{t+1}-$ while taking prices, $\left(w_{t}, R_{t+1}\right)$, and fiscal variables, $\left(\tau_{t}, \sigma_{t}, P_{t+1}\right)$ as given.

\footnotetext{
${ }^{7}$ In the appendix, we consider a popular reduced form specification of the "kids as consumption good" model, in which parents care about the number of kids, rather than about their utility (see Galor and Weil, 2000, Galor and Moav, 2002, de la Croix and Doepke, 2003, and van Groezen et al., 2003).
} 
To study the effects of the pension reforms, we consider an exogenous change in the pension benefits, $P_{t+1}$. Recall that the two Italian social security reforms of the 1990s provided a differential treatment to those with more than 15 years of contributions in 1992 (and 18 in 1995), who were mostly unaffected by the reforms, and to those with fewer years of contributions, who had their future pension benefits largely reduced. To capture this policy change, we consider two groups of individuals. Up to time $t$, all agents are identical. At time $t$, however, individuals in the affected group learn that they will experience a reduction in their future pension benefits, $P_{t+1}^{A}$, while the unaffected will not - hence, $P_{t+1}^{A}<P_{t+1}^{U}$. We then examine how this difference in future pension benefits influences the fertility decision in the two groups under the two motives for childbearing.

Finally, we model Italy as a small open economy, in which the social security reforms will not affect wages and rates of return ${ }^{8}$. In the theoretical model, we thus choose to focus specifically on the impact of the reforms on the fertility that takes place through the income effect, given that one group of workers faces an expected negative income effect, while the other does not. This represents the main effect in creating a potential gap in the fertility response of the two groups of individuals.

\subsection{Kids as Consumption Good}

This model generalizes the original specification presented by Becker and Barro (1988) to a two-period overlapping generations framework, in which individuals take saving and fertility decisions at the beginning of their working life (the first period) and retire - and leave bequest to their children - in the second period. Agents are altruistic towards their kids. In particular, individuals care about their own youth and old-age consumption, as well as about the youth and old-age consumption of all individuals in their dynasty, according to the following utility function:

\footnotetext{
${ }^{8}$ Several recent contributions (see Boldrin and Jones, 2002, and Boldrin, De Nardi and Jones, 2005) suggested that the effect of social security spending on fertility - both in the old-age security and in the kids as consumption good model - works also through general equilibrium effects. Namely, social security spending affects savings and thus the stock of capital. The resulting changes in prices, i.e., wages and rate of returns, then modify the optimal mix of investments in kids and assets.
} 


$$
\left(N_{t}\right)^{\mu}\left[U\left(c_{t}^{t}\right)+\beta U\left(c_{t+1}^{t}\right)\right]+\left(N_{t+1}\right)^{\mu}\left[U\left(c_{t+1}^{t+1}\right)+\beta U\left(c_{t+2}^{t+1}\right)\right]+\ldots
$$

where $N_{t}$ represents the number of individuals in the family dynasty at time $t$, and hence $N_{t+1}=N_{t} f_{t}$, and $c_{t}^{t}=C_{t}^{t} / N_{t}$ represents per-capita consumption. The degree of altruism towards the future generations is measured by the parameter $\mu$. We consider a CES utility function $U\left(C_{t}^{t}\right)=\left(C_{t}^{t}\right)^{\rho} / \rho$. As discussed in Jones and Schoonbroodt (2007), this optimization problem is compatible with two parametrizations: (i) $0<\rho<\mu<1$, as originally proposed by Becker and Barro (1988), and (ii) $\mu<\rho<0$, as suggested by Jones and Schoonbroodt (2007).

The problem of an altruistic individual thus amounts to maximize

$$
\sum_{t=0}^{\infty} \beta^{t}\left(N_{t}\right)^{\mu}\left[U\left(c_{t}^{t}\right)+\beta U\left(c_{t+1}^{t}\right)\right]
$$

subject to the budget constraints at equations 4.1 and 4.2 , where we set $d_{t}=d_{t+1}=$ 0 . Each individual chooses the amount of savings, $s_{t}$, and her fertility, $f_{t}-$ in the first period of her life, and the amount of bequest to her kids, $b_{t+1}$ - in the second period. The first order conditions of the optimization problem can be written respectively as:

$$
\left(C_{t+1}^{t}\right)^{\rho-1}=\beta R_{t+1}\left(C_{t}^{t}\right)^{\rho-1}
$$

for the saving decision,

$$
(\mu-\rho)\left(N_{t+1}\right)^{\mu} \frac{\left(C_{t+1}^{t+1}\right)^{\rho}+\beta\left(C_{t+2}^{t+1}\right)^{\rho}}{\rho f_{t}}=\left(\gamma R_{t+1}+b_{t+1}\right)\left(N_{t}\right)^{\mu}\left(C_{t+1}^{t}\right)^{\rho-1}
$$

for the fertility decision, and

$$
\left(N_{t+1}\right)^{\mu}\left(C_{t+1}^{t+1}\right)^{\rho-1}=f_{t}\left(N_{t}\right)^{\mu}\left(C_{t+1}^{t}\right)^{\rho-1}
$$

for the bequest decision.

While the first equation - determining the savings decision - has the usual interpretation, the second equation identifies the reasons for having kids in a Becker and Barro (1988) model. An additional kid increases the parents' utility due to the increase in the well-being of the offsprings ${ }^{9}$ (LHS of eq. 4.6), but reduces the

\footnotetext{
${ }^{9}$ Indeed, the children's utility is positive for $\rho>0$. In this case, an additional kid increases the parents' utility if $\mu>\rho>0$. For $\rho<0$, the children's utility is instead negative. In this case, an additional kid increases the parents' utility if $\mu<\rho<0$.
} 
consumption of the parents - and thus their utility - because kids are costly to raise and parents choose to endow them with a bequest (RHS of eq. 4.6). The third equation describes the trade-off associated with bequeathing wealth to the off-springs: a parent's lower consumption in old age (RHS of eq. 4.7) is compensated by the increase in consumption by the children who receive the transfer (LHS of eq. 4.7).

Using these first order conditions and the budget constraints, we can obtain an expression that implicitly describes the fertility decision of the individuals born at time $t$ :

$$
f_{t} \frac{\mu-\rho}{\rho R_{t+1}}+\frac{\left(f_{t}\right)^{\frac{1-\mu}{1-\rho}}}{\left(\beta R_{t+1}\right)^{\frac{1}{1-\rho}}} \frac{1+\left(\beta\left(R_{t+1}\right)^{\rho}\right)^{\frac{1}{1-\rho}}}{1+\left(\beta\left(R_{t+2}\right)^{\rho}\right)^{\frac{1}{1-\rho}}}=y_{t}+b_{t}+\frac{P_{t+1}}{R_{t+1}}
$$

Individuals who are negatively affected by the pension reform will have fewer resources to dedicate to their children in terms of raising costs and bequest. In particular, it is straightforward to see that - for both parametrizations regarding $\rho$ and $\mu$ - a reduction in the future pension benefit reduces the fertility rate, provided of course that kids are a normal good. The model presented in the appendix that uses a popular reduced form specification, in which parents care about the number of kids, rather than about their utility, provides the same qualitative results. Hence, if our empirical analysis were to find a reduction in fertility for the individuals affected by the Italian pension reforms of the 90 s, this result would be consistent with kids being a consumption good.

\subsection{Kids as an Investment Good}

In this specification, agents are altruistic towards their parents. Individuals care about their youth and old-age consumption and about their parents' old-age consumption. We consider the following logarithmic utility function:

$$
U\left(C_{t}^{t}\right)+\eta U\left(C_{t}^{t-1}\right)+\beta U\left(C_{t+1}^{t}\right) .
$$

where $C_{t}^{t-1}$ represents the old-age consumption for an individual born at time $t-1$, and $\eta$ is a measure of the kids-to-parents altruism. The budget constraints in youth and old age for an agent born at time $t$ correspond to the expressions at equations 4.1 and 4.2 , with $b_{t}=b_{t+1}=0$. 
In the first period of his life, each individual chooses the amount of savings, $s_{t}$, the fertility, $f_{t}$, and the amount of transfer to his parents, $d_{t}$, while taking prices, $\left(w_{t}, R_{t+1}\right)$ and fiscal variables, $\left(\tau_{t}, \sigma_{t}, P_{t+1}\right)$, as given, but forming expectations on the future transfers, $d_{t+1}$, that he may receive from his children. In choosing the transfer to their parents, we assume that children play a cooperative game among siblings, by jointly determining how much support to give to the parents ${ }^{10}$.

The first order conditions of the optimization problem are respectively:

$$
U^{\prime}\left(C_{t}^{t}\right)=\beta U^{\prime}\left(C_{t+1}^{t}\right) \frac{\partial C_{t+1}^{t}}{\partial s_{t}}
$$

for the saving decision,

$$
\gamma U^{\prime}\left(C_{t}^{t}\right)=\beta U^{\prime}\left(C_{t+1}^{t}\right) \frac{\partial C_{t+1}^{t}}{\partial f_{t}}
$$

for the fertility decision, and

$$
U^{\prime}\left(C_{t}^{t}\right)=\eta f_{t-1} U^{\prime}\left(C_{t}^{t-1}\right)
$$

for the transfer decision.

The last equation describes the trade-off associated with transferring resources to the parents: the lower consumption in youth has to be compensated by the utility provided by the parents' higher consumption, weighted by the degree of altruism and by the number of siblings that are also providing the transfer. The first two equations characterize the individual saving and fertility decision. It is important to notice that these decisions may influence the future transfer, $d_{t+1}$, that an individual may receive from his kids. Individuals take this element into account in their optimization problem and thus need to form expectations on this future transfer, $d_{t+1}$.

Starting from the optimization problem of the individuals at time $t+1$, simple algebra shows that, if these individuals optimally choose to save, i.e., for $s_{t+1}>0$, their transfer to the parents is equal to

$$
d_{t+1}=\frac{\eta}{1+\eta}\left(y_{t+1}+\frac{P_{t+2}}{R_{t+2}}\right)-\frac{1+\delta}{1+\eta+\delta} \frac{R_{t+1} s_{t}+P_{t+1}}{f_{t}}
$$

and the parents' old age consumption corresponds to

\footnotetext{
${ }^{10}$ Alternatively, children could play a non-cooperative Nash game among each other on how much to give to their parents (see also Boldrin and Jones, 2002).
} 


$$
C_{t+1}^{t}=\frac{\eta}{1+\eta} f_{t}\left(y_{t+1}+\frac{P_{t+2}}{R_{t+2}}\right)+\frac{\delta}{1+\eta+\delta}\left(R_{t+1} s_{t}+P_{t+1}\right) .
$$

Using the above equation and the first order conditions at equations 4.10 and 4.11, we can obtain the arbitrage condition that equalizes the returns from investing in assets and in kids at time $t$ :

$$
R_{t+1}=\frac{\eta}{\gamma \delta}\left(y_{t+1}+\frac{P_{t+2}}{R_{t+2}}\right)
$$

where the left hand side represents the return on the private assets and the right hand side measures the return from "investing" in kids, when the endogenous determination of the kid-to-parents transfers is taken into account.

Recall the policy experiment that we are considering: at time $t$, some individuals learn that their future pension benefits, $P_{t+1}^{A}$, will decrease. Interestingly, this change in the policy does not affect the return from investing in kids. This is because - as shown at eq. 4.13 - the kids adjust their transfers according to the old-age wealth of their parents, as measured by $R_{t+1} s_{t}+P_{t+1}$. Hence, the arbitrage condition that characterizes the saving and fertility decisions of the individuals at time $t$ continues to hold, unless there is a change in the future rates of returns, $R_{t+1}$ and $R_{t+2}$, or in the pension benefits at time $t+2$. If individuals at time $t$ were planning to "invest" both in assets and kids, i.e., $f_{t}>0$ and $s_{t}>0$, they will continue to do so even after learning about the reduction in their future pension benefits. Thus, we can use the first order conditions at eq. 4.10 and 4.11 , with $\frac{\partial C_{t+1}^{t}}{\partial s_{t}}$ and $\frac{\partial C_{t+1}^{t}}{\partial f_{t}}$ obtained from eq. 4.14, to evaluate the effect of a drop in the pension benefits on the individuals' fertility and savings decisions. Simple algebra shows that individuals who are negatively affected by the pension reform, $P_{t+1}^{A}<P_{t+1}^{U}$, will purchase more assets and will have more kids than the unaffected group, because of the negative income effect in old age. This is because individuals with lower pension benefits the affected group - will want to move more resources into the future to support their old age consumption. As the arbitrage condition is unaffected, and thus the returns of financial assets and fertility are unchanged, they will increase both asset holding and fertility.

To summarize, this model of old-age security suggests that the individuals af- 
fected by the Amato and Dini pension reform will save more - in assets and kids than the unaffected group. If the old-age security motive were still predominant in the Italian society in the 90s, our empirical results should unveil a higher fertility in the group of individuals negatively affected by the pension reforms.

\section{Context, Data and Identification Strategy}

In order to test the two fertility motives, we study the impact of Italian pension reforms on fertility choices for individuals and households who are affected, or unaffected. Italy represents a particularly interesting case for the study of fertility choices. Together with Spain, Italy has been the first country to steadily experience fertility levels below a threshold defined of "lowest-low fertility" (a total fertility rate of 1.3 children per woman or below) during the 1990s (Kohler et al., 2002). In order to visualize recent fertility developments, the Italian total fertility rate in the period 1970-2006 is compared those of Germany, Sweden and the United Kingdom in Figure 2. In the literature, there is no clear consensus on the reasons behind this sharp decline in fertility (nor on the recent increase), although a mix of cultural, economic and measurement factors are probably coexisting in shaping changes and cross-national differentials in the total fertility rate. Here we only focus on the motives that are consistent with the model previously discussed.

As anticipated, our identification strategy is based on comparing households who are affected by the Amato and Dini reforms (i.e., the treatment group) with those who are unaffected (i.e., the control group). We use self-reported data on years of contribution to separate, through the discontinuity introduced by the reforms, the treatment from the control group. The reforms affected couples in central childbearing ages for Italian standards. Men in married couples who had 15 years of contribution at the end of 1992 had on average about 35 years of age (to be precise, their average age in 1992 was 34.45 years). Their wives were on average 3.8 years younger (the average age of the wife in 1992 was 30.67 years). This age interval is particularly relevant, in contemporary Italy, for fertility choices. Although we later provide specific figures on the dataset we use, it is useful here to recall that fertility at ages $30+$ has been increasing ever since the mid 1980s (see Figure 3). Indeed, 
Italy has become the leading country in "late" childbearing (Billari et al., 2007). This is a clear consequence of the postponement of childbearing, a phenomenon that accompanies (and partly causes) the emergence of lowest-low fertility, and that is linked to a - at least partial - recuperation of the postponed births at later ages. It is therefore increasingly important, in the explanation of fertility, to understand the motives of childbearing of women ages 30, 35 or even more.

We analyze two specific datasets that we build using data from the Bank of Italy's Survey of Italian Households' Income and Wealth (SHIW from now onwards). This is a bi-annual survey, with some individuals repeatedly interviewed, which mostly collects, as the title says, data on income and wealth of Italian households. Crucial for our identification strategy is the fact that the SHIW contains data, provided by respondents, on the total number of years each household member has contributed to the pension system (at December 31st of the reference year of the survey). Given the strong attachment of Italian men to the labor market, we assume that the number of years of contributions at December 31st 1992 (or 1995), i.e., the reform reference date, can be derived from the number of years of contributions at December 31 st $1992+\lambda$, where $\lambda=6,8,10,12,14$, depending on the most recent SHIW wave for which a given respondent was interviewed. For example, a person who has at least 27 years of contributions in 2004 (December 31st) is assumed to have had at least 15 years of years of contributions in 1992 (December 31st) and therefore be unaffected by the reforms. On the contrary, a person who has 26 years of contributions in 2004 is assumed to have less than 15 years of contributions in 1992 - and thus be affected by the reforms. Reform is a therefore a simple dichotomous variable representing the treatment effect in this natural-experiment setting. Recall bias and lack of precision in reporting years of contributions certainly induce measurement error in the identification of the treatment and control group. However, the bias of such measurement error implies an underestimation of the effect of the reform, therefore the subsequent results might be conservative ${ }^{11}$. We use this strategy to identify affected and unaffected men, but we cannot use the same strategy for women, given their lower labor force participation, which is indeed

\footnotetext{
${ }^{11}$ The lack of more precise data on contributions (e.g. months, or weeks) prevents us from adopting a regression discontinuity design in subsequent analyses.
} 
related to fertility decisions and, even more problematically, the link between fertility and labor force withdrawal typical of the Italian case (Del Boca and Vuri, 2007). Consistently with the model, fertility is considered as a household decision. We focus on households with individuals who were married at the time of the surveys, and evaluate the effect of the reform focusing only on men as the affected or unaffected individuals. The focus on married couples should not bias our results, given the particularly low extra-marital birth rates and divorce rates during the period covered (see, e.g., Castiglioni and Dalla Zuanna, 2008).

We also exploit other data provided by the SHIW, such as the date of births of all household members, including husband, wife, and co-resident children. Moreover, we use data on the number (although not the date of birth) of non-resident children. We also include other control variables, such as educational level of both partners and the area of birth of the husband. We can reconstruct the couple's fertility history by using the date of birth of co-resident children. All non co-resident children are born before the time of the first reform, i.e. up to 1992 (this assumption does not affect subsequent results as we focus on childbirths from 1993 onwards). These assumptions are relatively mild in the case of Italy where children tend to co-reside with parents for a long time (well into their mid 20s). We only use data on household with wives born in 1955 or after (who are therefore not older than 41 in 1996).

A first test we conduct is a simple t-tests for the comparison of mean fertility of individuals who are just before (up to a year) and just after (up to a year) the threshold (15 years of contributions at the end of 1992, 18 years of contributions at the end of 1995) using information available or reconstructed at the time of the surveys. Table 1 contains the results of this test on these individuals who are as close to the discontinuity as we could get, performed on a sample of 201 unaffected individuals and 198 affected individuals. Indeed, while the number of children prior to 1993 is not significantly different between the two groups (nor it is for the number of children prior to 1996), fertility after the reforms is significantly higher for the treated. More specifically, after the Amato reform, affected individuals have on average 0.4899 children, while unaffected individuals have on average 0.3134 children during the same period, which includes the effect of both reforms. After the 1995 
Dini reform, affected individuals have on average 0.3586 children, while unaffected individuals have 0.2338 children during the same period. Our first evidence is therefore in favor of a significant, and sizable, negative effect of pensions on fertility, in accordance with the "old-age security" motive.

Whether a person is affected or not by the reforms depend on the assumption of continuous labor market attachment and on the good measurement of the variable of our interest. Moreover, other covariates may influence the estimation of the reform effect. The results of the simple comparison using t-tests displayed in Table 1 is subject to limitations. In particular, given the link between age at entry in the labor market and exposure to the reform, we can expect that unaffected individuals are, on average, older than affected individuals. If we take, as in Table 1, a one-year window around the reforms' threshold, we find that affected individuals (husbands) have an average age of 35.45 years, against an average age of 36.57 years for unaffected individuals. An average difference of one year in age translates almost equally into an average difference of one year in contributions. The same is true for the wives, as the average age of the wives of affected individuals is 31.67 years, against 32.88 years for the unaffected. Figures 4 and 5 show, however, that despite the average oneyear age difference between affected and unaffected individuals, there is a substantial amount of variability, with common support and an important overlap in the age distributions of affected and unaffected individuals. Therefore we choose to develop a series of regression models that control for the different age distribution, as well as for other potentially influential factors.

We extend the previous analysis with the inclusion of a series of control variables which are likely to affect both inclusion into the treatment or control group and fertility outcomes. In particular, we control for age (and education) of the husband, age (and education) of the wife, geographical area (using the area of birth of the husband). In order to have a more robust sample size, we also extend our sample to include individuals who are more distant from the discontinuity induced by the reform. In the next section, we will also carry some additional sensitivity analyses for the robustness of our results.

Most analyses are conducted using a dataset where we compare individuals who 
are up to 7 years below the threshold number of years of contributions (and thus affected by the reform) with individuals who are up to 7 above the threshold (unaffected). The sample size is 2,684, with 59.65 percent of individuals being affected by the reform. Table 2 presents descriptive statistics on this extended dataset (all variables, with the exception of fertility and reform refer to the time of the survey). We estimate simple OLS models of the type

$$
f_{i}=\beta_{0}^{0}+\beta_{1}^{0} \cdot \text { reform }_{i}+\beta_{2}^{0} \cdot x_{i}+\epsilon_{i}
$$

where $f_{i}$ is post-reform fertility for the $i$-th individual, Reform ${ }_{i}$ is a dichotomous indicator ( $=1$ if the $i$-th individual is affected, $=0$ otherwise), $x_{i}$ is a vector of control variables, $\epsilon_{i}$ is white noise. The estimated coefficient $\hat{\beta}_{1}^{0}$ is therefore the average effect of the reform on treated individuals on the number of post-reform children.

A second type of model focuses on the probability that at least one post-reform child is born, with a probit specification:

$$
\operatorname{Pr}\left(f_{i}>0\right)=\Phi^{-1}\left(\beta_{0}^{1}+\beta_{1}^{1} \cdot \text { Reform }_{i}+\beta_{2}^{1} \cdot x_{i}\right)
$$

where $\Phi^{-1}$ is the inverse standard-normal distribution, and the estimated coefficient $\hat{\beta}_{1}^{1}$ is the average effect (via inverse Mill's ratio) of the reform on the probability of having at least one post-reform child for treated individuals.

The data, however, contain more information than just the number of postreform children. More specifically, we can also exploit information on the timing of births, as is usually done in empirical analysis of fertility choices. Moreover, we can exploit the fact that some of the factors we focus on vary over the observation time (this is the case of husband's or wife's ages, or calendar year). To this purpose, we build a second dataset that contains observations in terms of persons-years, i.e., an entry for each individual $i$ in each given year of observation $j$, from 1993 onwards. In this second dataset, the age of husbands and wives is updated every year. The appropriate method to analyze persons-years datasets is discrete-time event history analysis (see, e.g., Jenkins, 1995) with the adoption of a hazard rate approach to the timing of births (see, e.g., Newman and McCulloch, 1984). Each household contributes to the sample as long as they are observed, and they leave the sample 
either when they are interviewed (in this case information is right-censored) or when they have another child. As the number of post-reform children is low on average, we only consider the progression to the first birth after the reform. Therefore, with the second dataset, we use a discrete-time probit specification, where the left-handside variable is the hazard rate, i.e. the annual probability of having an additional birth for the individual $i$ during the year $j$, given that the same individual has not yet had an additional birth in earlier years of observation:

$$
\operatorname{Pr}\left(B_{i}=j \mid B_{i} \geq j\right)=\Phi^{-1}\left(\beta_{0}^{2}+\beta_{1}^{2} \cdot \text { Reform }_{i}+\beta_{2}^{2} \cdot x_{i}+\beta_{3}^{2} \cdot v_{i j}\right)
$$

In eq. 5.3, $B_{i}$ denotes the time of first post-reform birth, $j$ is the year of observation, potentially between $1993(j=1)$ and $2006(j=14),\left(j=1, \ldots, J_{i}\right.$, where $J_{i}<14$ is the last year of observation for the $i$-th individual), $x_{i}$ is a vector of time-constant control variables, $v_{i j}$ is a vector of variables that vary across years. $\hat{\beta}_{1}^{2}$ is the estimated average effect (via inverse Mill's ratio) of the reform on the hazard of a post-reform birth for treated individuals.

\section{Results}

We now look at the results of our analysis (complete results of regressions and scripts are available upon request from the authors), starting from the study of the first dataset. Table 3 displays the results on the effect of the reform on the: a) number of children born starting from the year after each of the reforms and until the date of the survey (columns (1) and (2), OLS, as in eq. 5.1); b) probability of having an additional child during the same period (columns (3) and (4), Probit, as in eq. 5.2). The estimated effects of the reform are displayed in the "Reform" line (in terms of marginal effects for the Probit). In these regressions, we control for several elements that may affect the number of years of contributions individuals had in 1992 (and in 1995) and their fertility behavior. In particular, we carefully control for: age of husbands and wives (using age fixed-effects), level of education of husbands and of wives, geographical area, and the number of kids that they already had prior to the reforms. As might be expected, some of these controls have a significant effect. For instance, more educated women - who presumably decided to postpone fertility - 
are more likely to have kids after the reform. Individuals in the South are more likely to have children, whereas individuals who had more kids prior to the reform are less likely to have additional children afterwards. According to these estimates, after controlling for all these covariates, the average number of children for treated couples is 0.0529 higher since the 1992 reform (significant at the $10 \%$ level). The effect is positive (0.0329) but not statistically significant at the $10 \%$ level when we look at the post-1995 Dini reform only. The magnitude of the first effect should be compared to an average of 0.4010 post-reform children (i.e. it amounts to $13 \%$ higher fertility), and the magnitude of the second effect, which is however not statistically significant, to an average of 0.2957 post-Dini reform children (11\% higher fertility). Results on the Probit model on the probability of having an additional post-reform child also point towards the same direction: individuals who are affected by the reform have a $18.6 \%$ higher probability of having post-1992 reform children $(10.4 \%$, but not statistically significant, for the post-1995 reform effect).

Therefore, the findings from this regression confirm the direction of the effect found in Table 1, pointing towards the prevalence of an old-age security motive for childbearing. The joint effects of the two reforms (post-1992) is statistically significant (and strong). We know that the sharp effect of the Dini and Amato pension reform is documented by Bottazzi et al. (2006), who estimate for instance that, with a retirement age of 60 , the replacement rate (the ratio between pension income and work income before retirement) drops by 1 percent only for older private employees who had more than 27 years of contribution, compared to a drop by $12.4 \%$ for younger private employes. It is therefore not surprising that, if old-age security motive for childbearing prevails, this shows up as the effect of the pension reform.

From now onwards, our results refer to the second dataset, i.e., the one with discrete-time data on persons years, and to estimates based on eq. 5.3. We specify a model in which we estimate the joint effect of the reforms, i.e., the post-1992 effect. Table 4 displays the results of a first probit hazard model, in which age of the husband and age of the wife (using fixed-effects) are time-varying covariates, and in which we control for fixed period effects using dummy variables for each year. The marginal effect of the reform on the annual probability of having an additional birth 
is $0.67 \%$. This effect can be compared to the observed (average) annual probability, which is above $5 \%$. The reform is estimated to raise the annual probability of having a(nother) child by $12.7 \%$ in relative terms. The effect is statistically significant at the $5 \%$ level. This analysis, which makes use of additional information contained in the data and controls for time-varying effects, thus confirms the results obtained on the first dataset.

We now run two types of robustness checks for the reform effect using the second dataset. A first robustness check regards the size of the time window around the reform we use. Our standard models use a $+/-7$ year-wide window. The fact that age (controlled via fixed effects) is not behind the estimated effect is reassuring, but we conduct a second robustness check by using shorter time windows around the reform. Table 5 contains the output of such checks, compared to the reform effect displayed in Table 4 . The effect is stable with $\mathrm{a}+/-3$ year window. It is much higher, still significantly positive, but estimated with lower precision, as the window becomes the smallest one $(+/-1$ year). The stability of the estimates with the variation of the time window is a sign of robustness of the positive effect of the reform on fertility.

A second robustness check of our identification strategy is a placebo test, which is often used in studies that exploit discontinuities, like ours. More specifically, we estimate the effect of two discontinuities that we expect not to matter, as they are not in fact related to the reform. A first discontinuity ("Younger" placebo) is placed around 10 years of contributions in 1992, with a window of $+/-1$ years around the discontinuity. A second discontinuity ("Older" placebo) is placed around 20 years of contributions in 1992, with a window of $+/-1$ years around the discontinuity. The estimates of placebo effects are compared with the estimates of the reform effect with a $+/-1$ years time window in Table 6 . Indeed, placebo effects are not statistically significant, which is what we expect if our identification strategy through a discontinuity in years of contributions picks the reform effect: only the discontinuity around the actual reform matters.

A final piece of analysis concerns the differential effect of the reform on various categories of workers. As outlined in Section 3, the Amato and Dini reforms had a 
larger effect on public-sector dependent workers, followed by private-sector dependent workers and self-employed. We therefore develop a model in which the effect of the reform is interacted with the category of workers (unfortunately, this is only available at the time of the survey). Results, reported in Table 7, are consistent with the expectation (a larger effect for public-sector workers and a smaller effect for self-employed), although they are never statistically significant. This could point out to the fact that the differentials in the effect might simply be too small, or to the fact that our measurement of worker's category at the time of the survey does not precisely capture the actual category.

\section{Discussion}

Starting from the two main models of fertility decisions, we have designed a test of the "old-age security" motive for childbearing versus the classical Becker and Barro (1988) "kids as consumption good" motive in a contemporary low fertility society, characterized by strong family ties - Italy. We have exploited the discontinuity induced by two parallel pension reforms held in 1992 and 1995. Both reforms have generated a natural experiment that has exogenously reduced the pension income prospects of individuals with years of contribution below specific thresholds, while leaving others unaffected. We have estimated the effect of these changes on fertility.

Our results show that individuals who have lower pension income prospects, because they are affected by the reform, have significantly higher fertility. The relative increase of the realized fertility or of the probability of having a child is above $10 \%$. These findings are not in line with the "traditional" Becker and Barro (1988) theory of fertility based on consumption motives. Perhaps surprisingly, given the conventional wisdom for developed societies, they emphasize the relevance of the old-age security motive for fertility. This result is however consistent with the existence of strong family ties in the Italian, as well as in several other contemporary developed societies (see for instance the ranking according to a measure of family ties by Alesina and Giuliano, 2007). In these environments, parents may reasonably expect their kids to give them old-age support, for instance as in-kind or monetary transfers. Moreover, our findings are robust to different robustness checks, including 
several placebo tests.

We believe that our results are of general relevance for the study of fertility motives in developed societies, as they contribute to identify a clear negative impact of pension policy on fertility decisions. This is of particular relevance to the study of very-low and "lowest-low" fertility. If part of the fertility decline can be attributed to the diffusion of pension systems, the introduction of pension reforms that decrease the income prospects after retirement might contribute to a rise in fertility. Indeed, fertility in Italy had its minimum in 1996 and since then it is slowly rising. Further empirical evidence is needed on the contribution of the old-age security motive to total fertility in contemporary societies. Our results suggest that more research should be devoted to identify a more comprehensive model of fertility decisions which combines some characteristics of the two traditional fertility models existing in the literature with additional features that have recently gained importance in developed societies, such as in-kind and time transfers or personalized old age care. 


\section{References}

[1] Alesina, A. and P. Giuliano (2007) The Power of the Family, NBER Working Paper No. W13051.

[2] Attanasio, O.P. and Brugiavini, A. (2003) Social security and households' saving, Quarterly Journal of Economics, vol. 118, pp. 1075-1119.

[3] Barro, R. J. and Becker, G. (1989) Fertility choice in a model of economic growth, Econometrica, vol. 57, pp. 481-501.

[4] Becker, G. and Barro, R.J. (1988) A Reformulation of the Theory of Fertility, Quarterly Journal of Economics, vol. 103, pp. 1-25.

[5] Becker, G., K. Murphy, and R. Tamura (1990) Human Capital, Fertility, and Economic Growth, Journal of Political Economy, 98, 812-837.

[6] Bentolila, S, and A. Ichino (2008) Unemployment and Consumption near and far away from the Mediterranean, Journal of Population Economics, 21, pp. $255-280$.

[7] Billari, F.C. (2008) Lowest-Low Fertility in Europe: Exploring the Causes and Finding Some Surprises, The Japanese Journal of Population, vol. 6, pp. 2-18.

[8] Billari, F.C., Kohler, H.-P., Andersson, G., Lundstrom, H. (2007) Approaching the Limit: Long-Term Trends in Late and Very Late Fertility, Population and Development Review, vol. 33, pp. 149-170.

[9] Boldrin, M. and Jones, L. (2002) Mortality, Fertility and Saving in Malthusian Economy, Review of Economic Dynamics, vol. 5, pp. 775-814.

[10] Boldrin, M., De Nardi, M. and Jones, L. (2005) Fertility and Social Security, NBER w.p. 11146

[11] Bongaarts, J. (2004) Population Aging and the Rising Cost of Public Pensions, Population and Development Review, vol. 30, pp. 1-23 
[12] Bottazzi R,. Jappelli, T., and Padula, M. (2006) Retirement expectations, pension reforms, and their impact on private wealth accumulation, Journal of Public Economics, vol. 90, pp. 2187-2212.

[13] Brugiavini, A. and V. Galasso (2004) The Social Security Reform Process in Italy: where do we stand? Journal of Pension Economics and Finance, 1-31

[14] Cain, M. (1981) Risk and insurance: Perspectives on fertility and agrarian change in India and Bangladesh, Population and Development Review, vol. 7, pp. $435-474$.

[15] Caldwell, J.C. (1978) A Theory of Fertility: From High Plateau to Destabilization, Population and Development Review, vol. 4, pp. 553-577.

[16] Caldwell, J.C. (1982) Theory of Fertility Decline, New York: Academic Press.

[17] Castiglioni, M., Dalla Zuanna, G. (2008) Marital and Reproductive Behavior in Italy After 1995: Bridging the Gap with Western Europe?, European Journal of Population, OnlineFirst .

[18] Cigno, A. (1993) Intergenerational transfers without altruism. Family, market and state. European Journal of Political Economy vol. 9, pp. 505-518.

[19] Cigno, A. and Rosati, F. (1992) The effects of financial markets and social security on saving and fertility behaviour in Italy. Journal of Population Economics, $5,319-41$.

[20] Cigno, A. and Rosati, F. (1996) Joint determined saving and fertility behaviour: theory and estimates for Germany, Italy, the UK and USA, European Economic Review, 40, 1561-1589.

[21] Dalla Zuanna, G. (2001) The banquet of Aeolus: A familistic interpretation of Italy's lowest low fertility, Demographic Research, 4(5), 133-162.

[22] De la Croix, D., and M. Doepke (2003) Inequality and Growth: Why Differential Fertility Matters. The American Economic Review, 93(4), 1091-1113. 
[23] Del Boca, D., and D. Vuri (2007) The mismatch between employment and child care in Italy: the impact of rationing. Journal of Population Economics, 20(4), 805-832.

[24] Doepke, M. (2005) Child mortality and fertility decline: Does the Barro-Becker model fit the facts? Journal of Population Economics, 18(2), 337-366.

[25] Fenge, R. and Meier, V. (2004) Are family allowances and fertility-related pensions Siamese twins?, CESifo w.p. N. 1157

[26] Galasso, V., R. Gatti and P. Profeta (2009) Investing for the Old Age: Pension, Children and Savings. International tax and Public Finance.

[27] Galor, O. (2005) The Demographic Transition and the Emergence of Sustained Economic Growth Journal of the European Economic Association, 3(2-3), 494504.

[28] Galor, O., and O. Moav (2002) Natural Selection And The Origin Of Economic Growth The Quarterly Journal of Economics, 117(4), 1133-1191.

[29] Galor, O., and D. N. Weil (2000) Population, Technology, and Growth: From Malthusian Stagnation to the Demographic Transition and Beyond," The American Economic Review, 90(4), 806-28.

[30] Giuliano, P. (2007). Living Arrangements in Western Europe: Does Cultural Origin Matter? Journal of the European Economic Association, 5(5), 927-952.

[31] Goldstein, J.R., Lutz, W., and Testa M.-R. (2003) The Emergence of SubReplacement Fertility Ideals in Europe, Population Research and Policy Review Policy Review 22(5-6):479-496.

[32] Greenwood, J., A. Seshadri, and G. Vandenbroucke (2005) The Baby Boom and Baby Bust," The American Economic Review, 95 (1), 183-207.

[33] van Groezen, B. Leers, T. and Mejidam, L. (2003) Social security and endogenous fertility: pensions and child allowances as Siamese twins, Journal of Public Economics, vol. 87, pp. 233-251. 
[34] Jenkins, S.P. (1995) Easy estimation methods for discrete-time duration models, Oxford Bulletin of Economics and Statistics, vol. 57, 129-138.

[35] Jones, L. E., and A. Schoonbroodt (2007) Complements versus Substitutes and Trends in Fertility Choice in Dynastic Models, NBER Working Paper 13680

[36] Jones, L. E., A. Schoonbroodt, and M. Tertilt (2008) Fertility Theories: Can They Explain the Negative Fertility-Income Relationship?, mimeo

[37] Kagitcibasi, C. (1982) Old-age security value of children: Cross-national socioeconomic evidence, Journal of Cross-cultural Psychology, vol. 13, pp. 29-42.

[38] Kalmijn, M., Saraceno, C. (2008), A comparative perspective on intergenerational support: Responsiveness to parental needs in individualistic and familialistic countries, European Societies, 10(3), 479-509.

[39] Kohler, H.-P., Rodgers, J.L. and Christensen K. (1999) Is Fertility Behavior in our Genes: Findings from a Danish Twin Study, Population and Development Review 25(2), 253-288.

[40] Kohler, H.-P., Billari, F.C., Ortega, J.A. (2002) The Emergence of Lowest-Low Fertility in Europe during the 1990s, Population and Development Review, vol. 28, pp. 641-680.

[41] Leibenstein, H. (1957) Economic Backwardness and Economic Growth. New York: John Wiley.

[42] Manacorda, M. and Moretti, E. (2006) Why Do Most Italian Youths Live With Their Parents? Intergenerational Transfers and Household Structure, Journal of the European Economic Association, vol. 4, pp. 800-829.

[43] Manuelli. R., and Seshardi A. (2009) Explaining International Fertility Differences, Quarterly Journal of Economics.

[44] Mateos-Planas, X. (2002) The Demographic Transition in Europe: A Neoclassical Dynastic Approach Review of Economic Dynamics, 5(3), 646- 680. 
[45] Neher, P.A. (1971) Peasants, Procreation, and Pensions, American Economic Review, vol. 61, pp. 380-389.

[46] Newman, J.L. and McCulloch, C.E. (1984) A Hazard Rate Approach to the Timing of Births, Econometrica, 52(4), 939-961.

[47] Nugent, J.B. (1985) The Old-Age Security Motive for Fertility, Population and Development Review, vol. 11, pp. 75-97.

[48] Reher, D.S. (1998) Family ties in western Europe: Persistent contrasts, Population and Development Review, vol. 24, pp. 203-234.

[49] Rendall, M.S. and Bahchieva, R.A. (1998) An Old-Age Security Motive for Fertility in the United States?, Population and Development Review, vol. 24, pp. 293-307.

[50] Rodgers, J.L., Hughes, K., Kohler, H.-P., Christensen, K., Doughty, D., Rowe, D.C. and Miller, W.B. (2001) Genetic Influence Helps Explain Variation in Human Fertility Outcomes: Evidence from Recent Behavioral and Molecular Genetic Studies, Current Directions in Psychological Science, 10(5), 184-188.

[51] Sinn, H.-W. (2004) The pay-as-you go pension system as a fertility insurance and enforcement device, Journal of Public Economics, vol. 88, pp. 1335-57.

[52] Swidler, S. (1983) An empirical test of the effect of social security on fertility in the United States, American Economist, vol. 27, pp. 50-57.

[53] United Nations, Department of Economic and Social Affairs, Population Division (2007) World Population Prospects. The 2006 Revision. New York: United Nations. 


\section{Appendix}

\section{Another Model of "Kid as Consumption Good"}

A recent literature has used a reduced form version of the Becker-Barro model, in which individuals cares about their youth and old age consumption, and about the number of kids they have, according to the following utility function (see also Galor and Weil, 2000, Galor and Moav, 2002, de la Croix and Doepke, 2003, and van Groezen et al., 2003):

$$
U\left(C_{t}^{t}\right)+\delta U\left(f_{t}\right)+\beta U\left(C_{t+1}^{t}\right)
$$

where $\delta \geq 0$ is a parameter that measures the relative importance of the number of children in the individual utility function. To simplify the analysis, we use a logarithmic utility function, and assume that parents leave an exogenous bequest, $b_{t}$, to their children ${ }^{12}$.

Under this specification, the fertility choice is described by the following equation:

$$
\frac{\delta}{f_{t}}=\frac{1}{C_{t}^{t}}\left(\gamma+\frac{b_{t+1}}{R_{t+1}}\right)
$$

where the left hand side represents the marginal utility from having an additional child, and the right hand side the marginal disutility, in terms of consumption forgone in youth, due to the cost of raising the kid and of providing her with a bequest. Using this equation, the first order condition for the saving decision and the budget constraints at eq. 4.1 and 4.2 (with $d_{t}=d_{t+1}=0$ ), we can obtain the individual fertility decision at time $t$ :

$$
f_{t}=\frac{\delta}{1+\beta+\delta}\left(y_{t}+b_{t}+\frac{P_{t+1}}{R_{t+1}}\right) \frac{R_{t+1}}{\gamma R_{t+1}+b_{t+1}} .
$$

From this expression, it is easy to see that - for given levels of bequest $\left(b_{t}, b_{t+1}\right)$ - the affected group will have lower fertility than the unaffected group - that is, $f_{t}^{A}<f_{t}^{U}$ for $P_{t+1}^{A}<P_{t+1}^{U}$. This is entirely driven by the negative income effect. Individuals who are negatively affected by the pension reforms face a lower life time

\footnotetext{
${ }^{12}$ In the model at section 4.1 , the choice of the bequest is endogenous.
} 
income, and reduce their consumption of goods in youth and old age, as well as their "consumption of kids", provided that kids are not an inferior good.

Yet, the level of bequest is likely to depend (positively) on the parents life time income, since richer parents will leave more generous bequests to their children. With the bequest at time $t+1$ being a positive function of individuals' life time income, $b_{t+1}=b\left(Y_{t}\right)$ where $Y_{t}=y_{t}+b_{t}+P_{t+1} / R_{t+1}$, the impact of the pension reforms on the fertility of the affected group becomes:

$$
\frac{\partial f_{t}}{\partial P_{t+1}}=\frac{\delta}{1+\beta+\delta} \frac{R_{t+1}}{\gamma R_{t+1}+b_{t+1}}\left(1-\frac{b_{t+1}}{\gamma R_{t+1}+b_{t+1}} \varepsilon_{b, Y}\right)
$$

where $\varepsilon_{b, Y}=\frac{\partial b_{t+1}}{\partial Y_{t}} \frac{Y_{t}}{b_{t+1}}$. Thus, the affected group will have lower fertility than the unaffected group, i.e., $\partial f_{t} / \partial P_{t+1}>0$, if $\varepsilon_{b, Y}<1+\frac{\gamma R_{t+1}}{b_{t+1}}$; in other words, if the bequest to the children is not a superior good. Hence, if our empirical analysis were to suggest a reduction in fertility of the individuals affected by the Italian pension reforms of the $90 \mathrm{~s}$, this result would be consistent with kids being considered a consumption good. 
Figure 1. Pension Reforms in Italy (a)

\begin{tabular}{|c|c|c|c|}
\hline & Pre-1993 regime & 1992 reform & 1995 reform \\
\hline \multirow[t]{2}{*}{ Normal retirement age } & 60 (men) & 65 (men) & Any age after 56 (for both \\
\hline & 55(women) & 60(women) & men and women) \\
\hline Transitional period & & Until about 2032 & Until about 2035 \\
\hline \multirow[t]{4}{*}{ Pensionable earnings } & Average of last 5 years & Career average earnings & Career contributions \\
\hline & real earnings (converted & (converted to real values & (capitalized using a 5- \\
\hline & to real values through & through price index + & year moving average of \\
\hline & price index) & $1 \%)$ & GDP growth rate) \\
\hline \multirow[t]{7}{*}{ Pension benefit } & 2\%*(pensionable & 2\%*(pensionable & Proportional to \\
\hline & earnings)*(t), & earnings)*(t), & capitalized value of \\
\hline & where $t$ is years of tax & where $t$ is years of tax & career contributions, the \\
\hline & payments (at most 40) & payments (at most 40) & proportionality factor \\
\hline & & & increasing with age at \\
\hline & & & retirement (from .04720 \\
\hline & & & at age 57 to .06136 at age \\
\hline
\end{tabular}

65)

\begin{tabular}{|c|c|c|c|}
\hline Pension indexation & $\begin{array}{l}\text { Cost of living plus real } \\
\text { earnings growth }\end{array}$ & Cost of living & Cost of living \\
\hline Pension to survivor & $\begin{array}{c}60 \% \text { to spouse } \\
20 \% \text { to each child } \\
40 \% \text { to each child (if no } \\
\text { spouse) }\end{array}$ & Same & Same \\
\hline $\begin{array}{l}\text { Years of contributions } \\
\text { for eligibility }\end{array}$ & 15 & 20 & 5 \\
\hline $\begin{array}{c}\text { Early retirement } \\
\text { provision }\end{array}$ & $\begin{array}{l}\text { Any age if contributed to } \\
\text { SS for } 35 \text { years or more, } \\
\text { no actuarial adjustment }\end{array}$ & $\begin{array}{l}\text { Any age if contributed to } \\
\text { SS for } 35 \text { years or more, } \\
\text { no actuarial adjustment }\end{array}$ & $\begin{array}{l}\text { No early retirement } \\
\text { provision }\end{array}$ \\
\hline Total Payroll tax & $24.5 \%$ of gross earnings & $27.17 \%$ of gross earnings & $32.7 \%$ of gross earnings \\
\hline
\end{tabular}


Figure 2: Total fertility rates in four European countries: 1970-2006

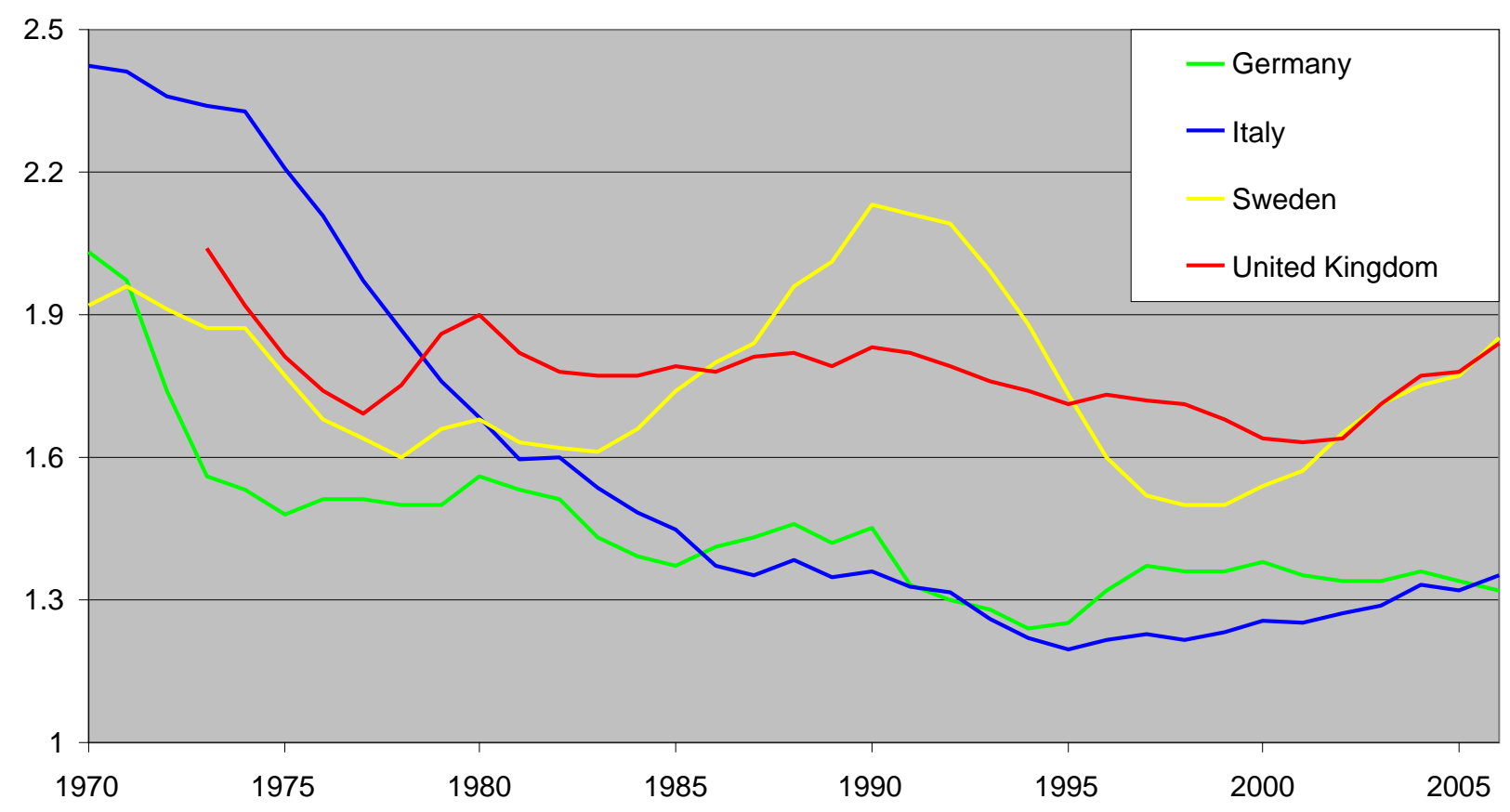

Figure 3: Total fertility rates (only women aged $30+$ ) in four European countries: 1970-2006

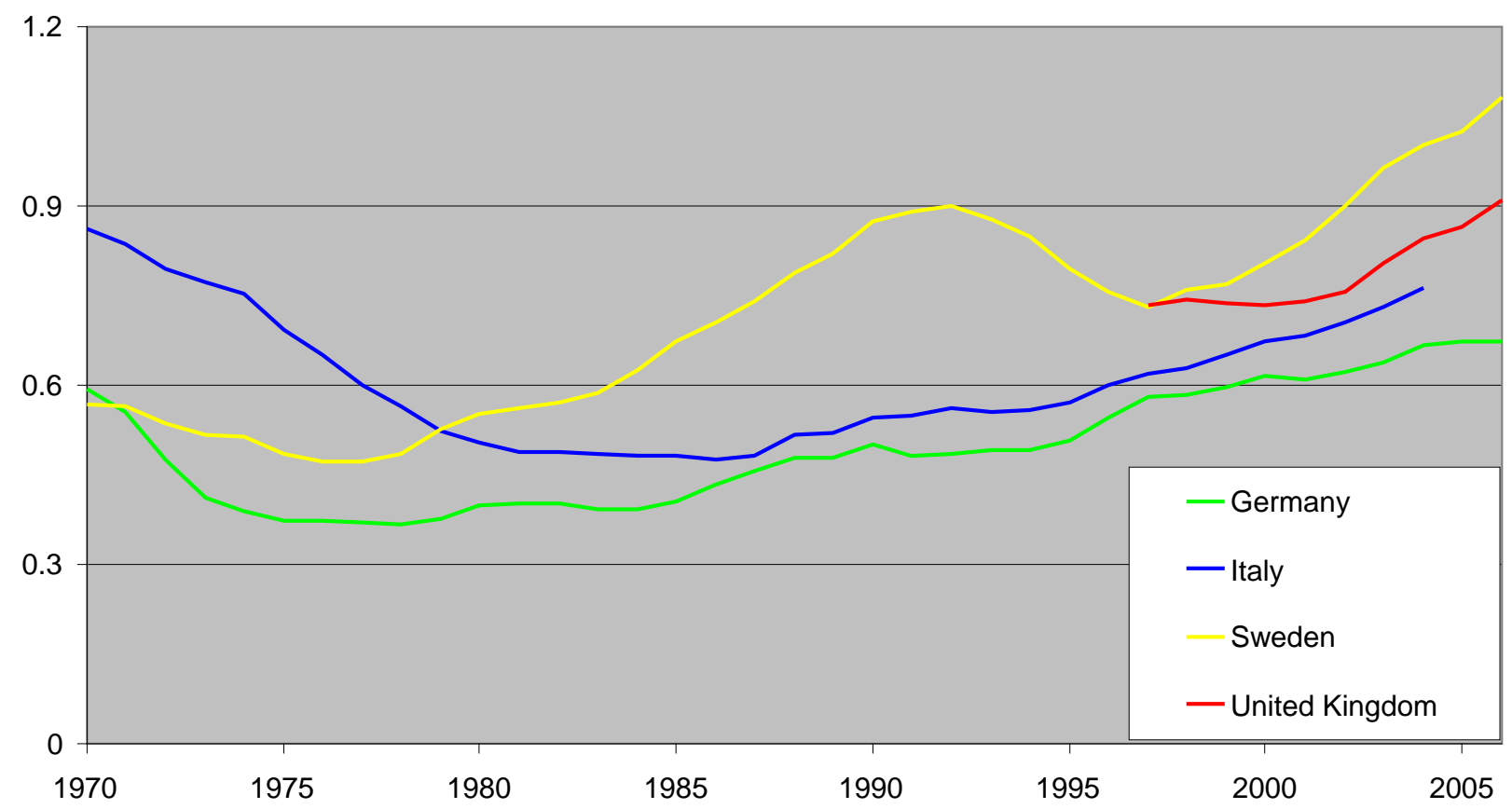


Figure 4. Age distribution in 1993 for husbands unaffected and affected by the reforms. Window: +/- 1 year of contributions around the reforms' thresholds, women born 1955 or after.

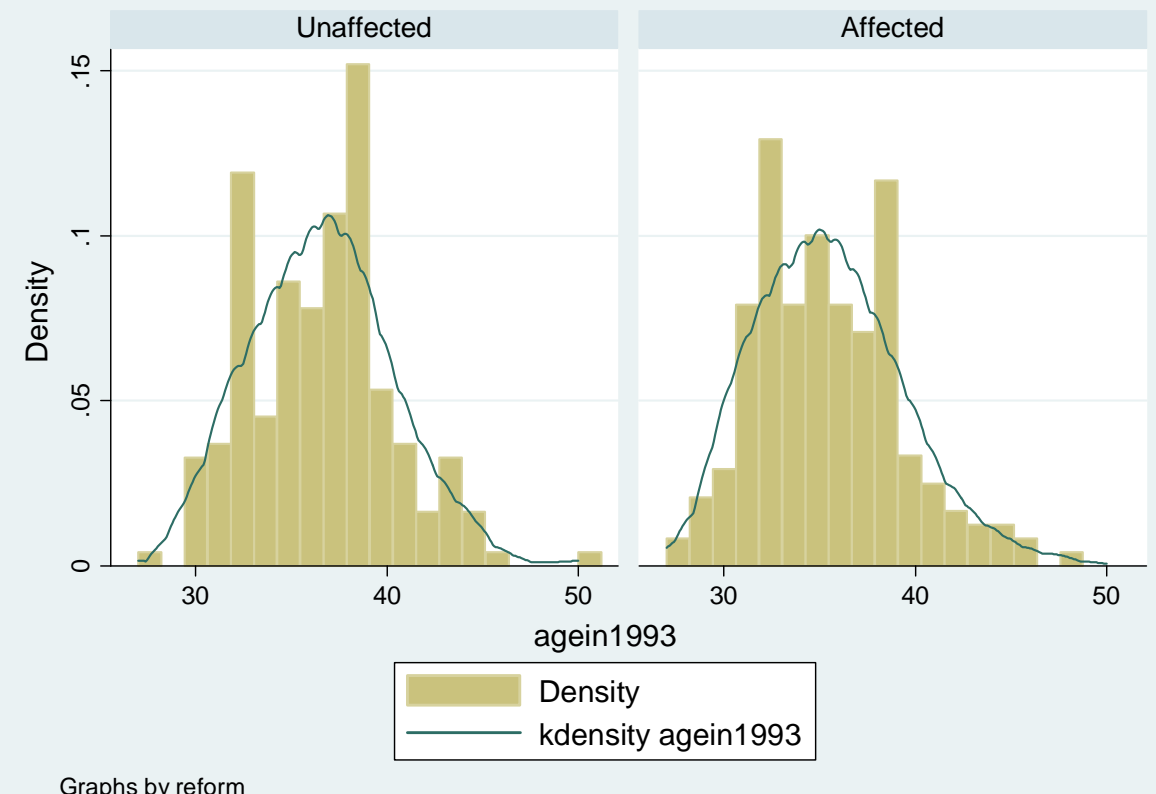

Mean age in 1993 for $\mathrm{N}=201$ unaffected=36.57 years, for $\mathrm{N}=198$ affected=35.45 years. Difference significant at the $1 \%$ level (t-test).

Figure 5. Age distribution in 1993 for wives unaffected and affected by the reforms. Window: +/- 1 year of contributions around the reforms' thresholds, women born 1955 or after.

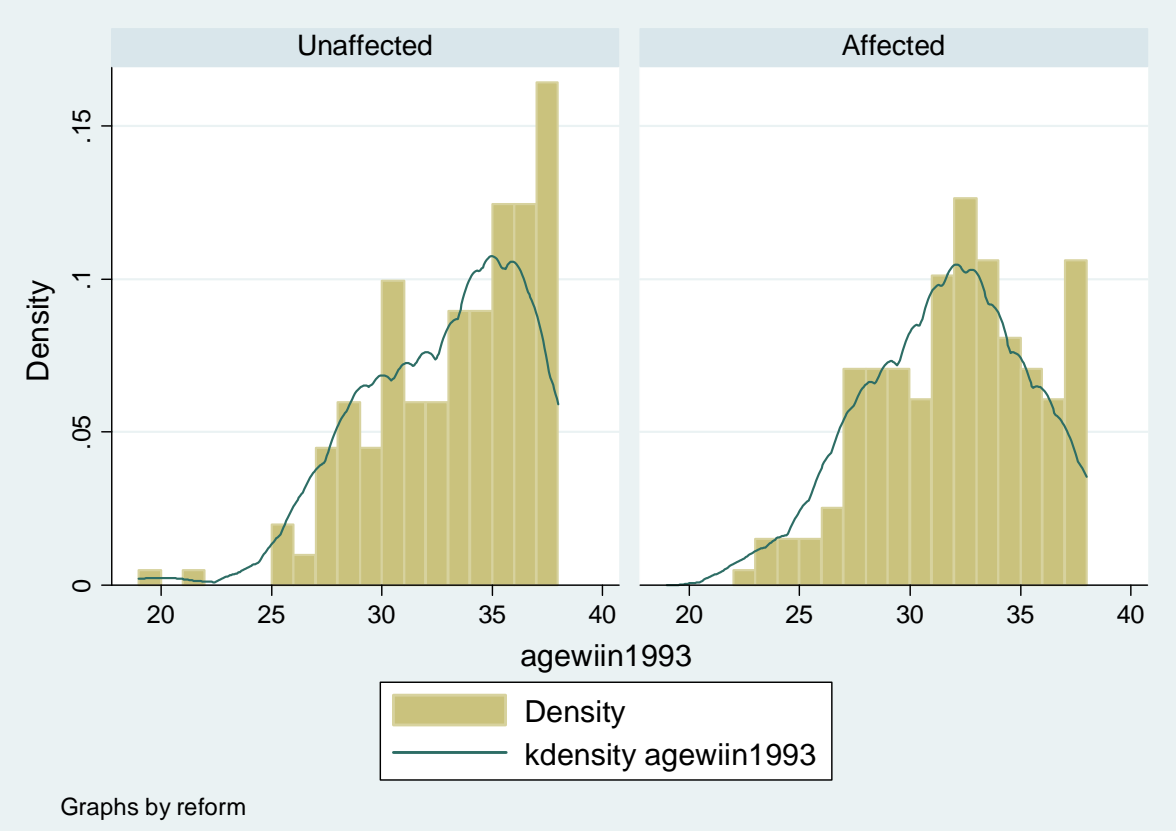

Mean age in 1993 for $\mathrm{N}=201$ unaffected=32.88 years, for $\mathrm{N}=198$ affected=31.67 years. Difference significant at the $1 \%$ level (t-test). 
Table 1. Differences between individuals who are affected and unaffected by the reforms. +/1 year-window around the reforms' thresholds.

\begin{tabular}{lcc}
\hline & $\begin{array}{c}\text { Unaffected } \\
\text { (up to - 1 year) }\end{array}$ & $\begin{array}{c}\text { Affected } \\
\text { (up to +1 year) }\end{array}$ \\
\hline Number of children (up to 1993) & 1.3831 & 1.3788 \\
& $(0.0742)$ & $(0.0802)$ \\
Number of children (after 1993) & 0.3134 & $0.4899^{* * *}$ \\
& $(0.0421)$ & $(0.0468)$ \\
Number of children (up to 1996) & 1.4627 & 1.5101 \\
& $(0.0730)$ & $(0.0800)$ \\
Number of children (after 1996) & 0.2338 & $0.3586^{* *}$ \\
& $(0.0360)$ & $(0.0410)$ \\
Total number of children (up to 2006) & 1.6965 & $1.8687^{*}$ \\
& $(0.0699)$ & $(0.0772)$ \\
$N$ & & \\
& & \\
& & \\
\end{tabular}

Standard errors in parentheses.

Significance levels on the 2-tail t-test on the hypothesis of difference between the affected and the unaffected: * significant at $10 \%$; ** significant at $5 \%$; *** significant at $1 \%$

Source: own analyses on Bank of Italy's Survey on Household Income and Wealth (joint dataset waves 1998, 2000, 2002, 2004, 2006). 
Table 2. Descriptive statistics for variables used in subsequent analyses. Window: $+/-7$ years of contributions around the reforms' thresholds, women born 1955 or after.

\begin{tabular}{|c|c|c|}
\hline & Mean & s.d. \\
\hline Reform (dummy) & 0.5965 & \\
\hline Number of children (up to 1993) & 1.2522 & 1.0260 \\
\hline Number of children (after 1993) & 0.5089 & 0.7338 \\
\hline Number of children (up to 1996) & 1.3864 & 1.0213 \\
\hline Number of children (after 1996) & 0.3748 & 0.6382 \\
\hline Education (husband, years) & 10.4411 & 3.4473 \\
\hline Education (wife, years) & 10.6971 & 3.4377 \\
\hline Age at interview (husband) & 45.6997 & 5.4437 \\
\hline Age at interview (wife) & 41.6651 & 5.1768 \\
\hline Center as area of birth (dummy) & .1803 & \\
\hline South as area of birth (dummy) & .3882 & \\
\hline Survey year 1998 (dummy) & .0384 & \\
\hline Survey year 2000 (dummy) & .2086 & \\
\hline Survey year 2002 (dummy) & .2198 & \\
\hline Survey year 2004 (dummy) & .1907 & \\
\hline $\mathrm{N}$ & 2684 & \\
\hline
\end{tabular}

Source: own analyses on Bank of Italy's Survey on Household Income and Wealth (joint dataset waves 1998, 2000, 2002, 2004, 2006). 
Table 3. Effect of pension reforms on post-reform fertility (total number of children or probability of having at least an additional child). Window: +/- 7 years of contributions around the reforms' thresholds, women born 1955 or after.

\begin{tabular}{|c|c|c|c|c|}
\hline & (1) & (2) & (3) & (4) \\
\hline & $\begin{array}{l}\text { OLS Amato+Dini } \\
\text { Reform }\end{array}$ & $\begin{array}{l}\text { OLS Dini Reform } \\
\text { only }\end{array}$ & $\begin{array}{l}\text { Probit Amato+Dini } \\
\text { Reform } \\
\text { (marginal effect) }\end{array}$ & $\begin{array}{c}\text { Probit Dini } \\
\text { Reform only } \\
\text { (marginal effect) }\end{array}$ \\
\hline Reform & $\begin{array}{l}0.0529 * \\
(0.0287)\end{array}$ & $\begin{array}{c}0.0329 \\
(0.0253)\end{array}$ & $\begin{array}{c}0.0717 * * * \\
(0.0247)\end{array}$ & $\begin{array}{c}0.0312 \\
(0.0227)\end{array}$ \\
\hline $\begin{array}{l}\text { Education } \\
\text { (husband) }\end{array}$ & $\begin{array}{c}0.00465 \\
(0.00437)\end{array}$ & $\begin{array}{c}0.00392 \\
(0.00386)\end{array}$ & $(0.00391)$ & $(0.00350)$ \\
\hline $\begin{array}{l}\text { Education } \\
\text { (wife) }\end{array}$ & $\begin{array}{l}0.0166^{* * * *} \\
(0.00428)\end{array}$ & $\begin{array}{l}0.0158^{* * *} \\
(0.00377)\end{array}$ & $\begin{array}{l}0.0159 * * * \\
(0.00377)\end{array}$ & $\begin{array}{c}0.0173 * * * \\
(0.00332)\end{array}$ \\
\hline Center & $\begin{array}{l}-0.00184 \\
(0.0339)\end{array}$ & $\begin{array}{l}0.00762 \\
(0.0299)\end{array}$ & $\begin{array}{c}0.0318 \\
(0.0300)\end{array}$ & $\begin{array}{c}0.0199 \\
(0.0267)\end{array}$ \\
\hline South & $\begin{array}{c}0.108 * * * \\
(0.0286)\end{array}$ & $\begin{array}{c}0.0848 * * * \\
(0.0253)\end{array}$ & $\begin{array}{c}0.0865 * * * \\
(0.0253)\end{array}$ & $\begin{array}{c}0.0736 * * * \\
(0.0227)\end{array}$ \\
\hline Year 1998 & $\begin{array}{c}-0.728 * * * \\
(0.0726)\end{array}$ & $\begin{array}{c}-0.652 * * * \\
(0.0636)\end{array}$ & $\begin{array}{c}-0.340 * * * \\
(0.0174)\end{array}$ & $\begin{array}{c}-0.254 * * * \\
(0.0113)\end{array}$ \\
\hline Year 2000 & $\begin{array}{c}-0.457^{* * *} \\
(0.0412)\end{array}$ & $\begin{array}{c}-0.451 * * * \\
(0.0362)\end{array}$ & $\begin{array}{c}-0.291 * * * \\
(0.0251)\end{array}$ & $\begin{array}{c}-0.269 * * * \\
(0.0176)\end{array}$ \\
\hline Year 2002 & $\begin{array}{c}-0.320 * * * \\
(0.0369)\end{array}$ & $\begin{array}{c}-0.295^{* * *} \\
(0.0325)\end{array}$ & $\begin{array}{c}-0.215^{* * *} \\
(0.0259)\end{array}$ & $\begin{array}{c}-0.202 * * * \\
(0.0193)\end{array}$ \\
\hline Year 2004 & $\begin{array}{c}-0.149 * * * \\
(0.0360)\end{array}$ & $\begin{array}{c}-0.115^{* * *} \\
(0.0317)\end{array}$ & $\begin{array}{c}-0.103 * * * \\
(0.0283)\end{array}$ & $\begin{array}{c}-0.0825^{* * *} \\
(0.0233)\end{array}$ \\
\hline $\begin{array}{l}\text { Number of children } \\
\text { (up to 1993) }\end{array}$ & $\begin{array}{c}-0.175^{* * *} \\
(0.0141)\end{array}$ & & $\begin{array}{c}-0.132 * * * \\
(0.0126)\end{array}$ & \\
\hline $\begin{array}{l}\text { Number of children } \\
\text { (up to 1996) }\end{array}$ & & $\begin{array}{c}-0.134^{* * *} \\
(0.0121)\end{array}$ & & $\begin{array}{c}-0.102^{* * *} \\
(0.0109)\end{array}$ \\
\hline Constant & $\begin{array}{l}-0.105 \\
(0.678)\end{array}$ & $\begin{array}{c}0.146 \\
(0.598)\end{array}$ & & \\
\hline $\begin{array}{l}\text { Age fixed effects } \\
\text { (husband) }\end{array}$ & YES & YES & YES & YES \\
\hline $\begin{array}{l}\text { Age fixed effects } \\
\text { (wife) }\end{array}$ & YES & YES & YES & YES \\
\hline $\begin{array}{l}N \\
R \text {-squared }\end{array}$ & $\begin{array}{l}2684 \\
0.320\end{array}$ & $\begin{array}{l}2684 \\
0.299\end{array}$ & 2661 & 2661 \\
\hline Observed $P$ & & & 0.3856 & 0.2996 \\
\hline
\end{tabular}

Standard errors in parentheses. ${ }^{* * *} p<0.01,{ }^{* *} p<0.05, * p<0.1$ 
Table 4. Marginal effect of pension reforms on the annual probability of having an additional child (discrete-time probit event-history model on persons-years). Window: $+/-7$ years of contributions around the reforms' thresholds, women born 1955 or after.

\begin{tabular}{|c|c|}
\hline & $\begin{array}{c}\text { Person-period } \\
\text { Probit Amato+Dini }\end{array}$ \\
\hline Reform & $\begin{array}{c}0.00664 * * \\
(0.00286)\end{array}$ \\
\hline Education (husband) & $\begin{array}{c}0.000583 \\
(0.000427)\end{array}$ \\
\hline Education (wife) & $\begin{array}{l}0.00152 * * * \\
(0.000402)\end{array}$ \\
\hline Center & $\begin{array}{l}0.0100 * * * \\
(0.00285)\end{array}$ \\
\hline South & $\begin{array}{c}0.00291 \\
(0.00328)\end{array}$ \\
\hline Number of children (up to 1993) & $\begin{array}{c}-0.0145 * * * \\
(0.00147)\end{array}$ \\
\hline $\begin{array}{l}\text { Age fixed effects (husband, time- } \\
\text { varying) }\end{array}$ & YES \\
\hline $\begin{array}{l}\text { Age fixed effects (wife, time- } \\
\text { varying) }\end{array}$ & YES \\
\hline $\begin{array}{l}\text { Year fixed effects (husband, time- } \\
\text { varying) }\end{array}$ & YES \\
\hline $\begin{array}{l}\text { Year fixed effects (wife, time- } \\
\text { varying) }\end{array}$ & YES \\
\hline$N$ (persons-years) & 19760 \\
\hline Observed P & 0.0522 \\
\hline
\end{tabular}


Table 5. Marginal effect of pension reforms on the annual probability of having an additional child (discrete-time probit event-history model on persons-years) (varying window around the reforms' thresholds, women born 1955 or after).

$\begin{array}{lll}\text { (1) } & (2) & (3) \\ \text { window: } & \text { window: } & \text { window: } \\ \text { +/- 7 years } & \text { +/- 3 years } & \text { +/- 1 year }\end{array}$

$\begin{array}{llll}\text { Reform } & 0.00664 * * & 0.00662 * & 0.0169 * * \\ (0.00286) & (0.00341) & (0.00727)\end{array}$

$N$ (persons- $\quad 19760 \quad 9153 \quad 2450$

years)

$\begin{array}{llll}\text { Observed } P & 0.0522 & 0.0485 & 0.0535\end{array}$

Standard errors in parentheses. * significant at 10\%; ** significant at 5\%; *** significant at $1 \%$

Source: own analyses on Bank of Italy’s Survey on Household Income and Wealth (joint dataset waves 1998, 2000, 2002, 2004, 2006, persons-years reconstruction).

Same control variables as for the models in Table 4.

Table 6. Marginal effect of pension reforms on the annual probability of having an additional child (discrete-time probit event-history model on persons-years): placebo test (one-year window around the reforms' thresholds, women born 1955 or after).

\begin{tabular}{|c|c|c|c|}
\hline & $\begin{array}{l}(1) \\
\text { "Younger" } \\
\text { placebo } \\
\text { (window: } \\
\text { +/- } 1 \text { year) }\end{array}$ & $\begin{array}{l}(2) \\
\text { Real } \\
\text { reform } \\
\text { (window: } \\
+/-1 \text { year) }\end{array}$ & $\begin{array}{l}(3) \\
\text { "Older" } \\
\text { placebo } \\
\text { (window: } \\
\text { +/- } 1 \text { year) }\end{array}$ \\
\hline Reform & $\begin{array}{r}-0.00850 \\
(0.0118)\end{array}$ & $\begin{array}{l}0.0169 * * \\
(0.00727)\end{array}$ & $\begin{array}{c}0.00426 \\
(0.00482)\end{array}$ \\
\hline $\begin{array}{l}N \text { (persons- } \\
\text { years) }\end{array}$ & 2198 & 2450 & 1147 \\
\hline Observed P & 0.0996 & 0.0535 & 0.0235 \\
\hline \multicolumn{4}{|c|}{$\begin{array}{l}\text { Standard errors in parentheses } \\
* \text { significant at 10\%; ** significant at 5\%; *** significant at 1\% } \\
\text { Source: own analyses on Bank of Italy's Survey on Household Income and Wealth (joint dataset waves 1998, 2000, } \\
\text { 2002, 2004, persons-years reconstruction). } \\
\text { Same control variables as for the models in Table 4. The "Younger" placebo model estimates the effect of a } \\
\text { discontinuity around } 10 \text { years of contributions in 1992, with a window of }+/-1 \text { year around the discontinuity. The } \\
\text { "Older" placebo model estimates the effect of a discontinuity around } 20 \text { years of contributions in 1992, with a } \\
\text { window of }+/-1 \text { year around the discontinuity. }\end{array}$} \\
\hline
\end{tabular}


Table 7. Marginal effect of pension reforms on the annual probability of having an additional child for various groups of workers (discrete-time probit event-history model on persons-years) (varying window around the reforms' thresholds, women born 1955 or after).

(1)

Person-period Probit Amato+Dini

$\begin{array}{lc}\text { Reform } & 0.00603 * \\ & (0.00316) \\ \text { Reform*Public sector } & 0.00149 \\ & (0.00364) \\ \text { Reform*Self-employed } & 0.00103 \\ & (0.00323)\end{array}$

$N$ (persons-years)

19760

Observed P

0.0522

Standard errors in parentheses

* significant at 10\%; ** significant at 5\%; *** significant at $1 \%$

Source: own analyses on Bank of Italy's Survey on Household Income and Wealth (joint dataset waves 1998, 2000, 2002, 2004, persons-years reconstruction).

Same control variables as for the models in Table 4. 


\section{CESifo Working Paper Series}

for full list see www.cesifo-group.org/wp

(address: Poschingerstr. 5, 81679 Munich, Germany, office@cesifo.de)

2581 António Afonso and Christophe Rault, Bootstrap Panel Granger-Causality between Government Budget and External Deficits for the EU, March 2009

2582 Bernd Süssmuth, Malte Heyne and Wolfgang Maennig, Induced Civic Pride and Integration, March 2009

2583 Martin Peitz and Markus Reisinger, Indirect Taxation in Vertical Oligopoly, March 2009

2584 Petra M. Geraats, Trends in Monetary Policy Transparency, March 2009

2585 Johannes Abeler, Armin Falk, Lorenz Götte and David Huffman, Reference Points and Effort Provision, March 2009

2586 Wolfram F. Richter, Taxing Education in Ramsey’s Tradition, March 2009

2587 Yin-Wong Cheung, Menzie D. Chinn and Eiji Fujii, China's Current Account and Exchange Rate, March 2009

2588 Alexander Haupt and Silke Uebelmesser, Voting on Labour-Market Integration and Education Policy when Citizens Differ in Mobility and Ability, March 2009

2589 Hans Jarle Kind, Marko Koethenbuerger and Guttorm Schjelderup, Should UtilityReducing Media Advertising be Taxed?, March 2009

2590 Alessandro Cigno, How to Avoid a Pension Crisis: A Question of Intelligent System Design, March 2009

2591 Helmut Lütkepohl and Fang Xu, The Role of the Log Transformation in Forecasting Economic Variables, March 2009

2592 Rainald Borck, Hyun-Ju Koh and Michael Pflüger, Inefficient Lock-in and Subsidy Competition, March 2009

2593 Paolo M. Panteghini, On the Equivalence between Labor and Consumption Taxation, March 2009

2594 Bruno S. Frey, Economists in the PITS?, March 2009

2595 Natalie Chen and Dennis Novy, International Trade Integration: A Disaggregated Approach, March 2009

2596 Frédérique Bec and Christian Gollier, Term Structure and Cyclicity of Value-at-Risk: Consequences for the Solvency Capital Requirement, March 2009 
2597 Carsten Eckel, International Trade and Retailing, March 2009

2598 Gianni De Nicolò and Iryna Ivaschenko, Global Liquidity, Risk Premiums and Growth Opportunities, March 2009

2599 Jay Pil Choi and Heiko Gerlach, International Antitrust Enforcement and Multi-Market Contact, March 2009

2600 Massimo Bordignon and Guido Tabellini, Moderating Political Extremism: Single Round vs Runoff Elections under Plurality Rule, April 2009

2601 Ana B. Ania and Andreas Wagener, The Open Method of Coordination (OMC) as an Evolutionary Learning Process, April 2009

2602 Simon Gächter, Daniele Nosenzo, Elke Renner and Martin Sefton, Sequential versus Simultaneous Contributions to Public Goods: Experimental Evidence, April 2009

2603 Philippe Jehiel and Andrew Lilico, Smoking Today and Stopping Tomorrow: A Limited Foresight Perspective, April 2009

2604 Andreas Knabe, Steffen Rätzel, Ronnie Schöb and Joachim Weimann, Dissatisfied with Life, but Having a Good Day: Time-Use and Well-Being of the Unemployed, April 2009

2605 David Bartolini and Raffaella Santolini, Fiscal Rules and the Opportunistic Behaviour of the Incumbent Politician: Evidence from Italian Municipalities, April 2009

2606 Erkki Koskela and Jan König, Can Profit Sharing Lower Flexible Outsourcing? A Note, April 2009

2607 Michel Beine, Frédéric Docquier and Çağlar Özden, Diasporas, April 2009

2608 Gerd Ronning and Hans Schneeweiss, Panel Regression with Random Noise, April 2009

2609 Adam S. Booij, Bernard M.S. van Praag and Gijs van de Kuilen, A Parametric Analysis of Prospect Theory's Functionals for the General Population, April 2009

2610 Jeffrey R. Brown, Julia Lynn Coronado and Don Fullerton, Is Social Security Part of the Social Safety Net?, April 2009

2611 Ali Bayar and Bram Smeets, Economic, Political and Institutional Determinants of Budget Deficits in the European Union, April 2009

2612 Balázs Égert, The Impact of Monetary and Commodity Fundamentals, Macro News and Central Bank Communication on the Exchange Rate: Evidence from South Africa, April 2009

2613 Michael Melvin, Christian Saborowski, Michael Sager and Mark P. Taylor, Bank of England Interest Rate Announcements and the Foreign Exchange Market, April 2009 
2614 Marie-Louise Leroux, Pierre Pestieau and Gregory Ponthiere, Should we Subsidize Longevity?, April 2009

2615 Ronald MacDonald, Lukas Menkhoff and Rafael R. Rebitzky, Exchange Rate Forecasters' Performance: Evidence of Skill?, April 2009

2616 Frederick van der Ploeg and Steven Poelhekke, The Volatility Curse: Revisiting the Paradox of Plenty, April 2009

2617 Axel Dreher, Peter Nunnenkamp, Hannes Öhler and Johannes Weisser, Acting Autonomously or Mimicking the State and Peers? A Panel Tobit Analysis of Financial Dependence and Aid Allocation by Swiss NGOs, April 2009

2618 Guglielmo Maria Caporale, Roman Matousek and Chris Stewart, Rating Assignments: Lessons from International Banks, April 2009

2619 Paul Belleflamme and Martin Peitz, Asymmetric Information and Overinvestment in Quality, April 2009

2620 Thomas Dohmen, Armin Falk, David Huffman and Uwe Sunde, Are Risk Aversion and Impatience Related to Cognitive Ability?, April 2009

2621 Yin-Wong Cheung and Xingwang Qian, The Empirics of China's Outward Direct Investment, April 2009

2622 Frédérique Bec and Christian Gollier, Assets Returns Volatility and Investment Horizon: The French Case, April 2009

2623 Ronnie Schöb and Marcel Thum, Asymmetric Information Renders Minimum Wages Less Harmful, April 2009

2624 Martin Ruf and Alfons J. Weichenrieder, The Taxation of Passive Foreign Investment Lessons from German Experience, April 2009

2625 Yao Li, Borders and Distance in Knowledge Spillovers: Dying over Time or Dying with Age? - Evidence from Patent Citations, April 2009

2626 Jim Malley and Ulrich Woitek, Technology Shocks and Aggregate Fluctuations in an Estimated Hybrid RBC Model, April 2009

2627 Jin Cao and Gerhard Illing, Endogenous Systemic Liquidity Risk, April 2009

2628 Thiess Buettner and Bjoern Kauder, Revenue Forecasting Practices: Differences across Countries and Consequences for Forecasting Performance, April 2009

2629 Håkan Selin, The Rise in Female Employment and the Role of Tax Incentives - An Empirical Analysis of the Swedish Individual Tax Reform of 1971, April 2009

2630 Nick Johnstone and Ivan Hascic, Environmental Policy Design and the Fragmentation of International Markets for Innovation, April 2009 
2631 Spiros Bougheas, Richard Kneller and Raymond Riezman, Optimal Education Policies and Comparative Advantage, April 2009

2632 Jay Pil Choi and Heiko Gerlach, Multi-Market Collusion with Demand Linkages and Antitrust Enforcement, April 2009

2633 Thor O. Thoresen, Income Mobility of Owners of Small Businesses when Boundaries between Occupations are Vague, April 2009

2634 Guido Schwerdt and Amelie C. Wuppermann, Is Traditional Teaching really all that Bad? A Within-Student Between-Subject Approach, April 2009

2635 Kurt R. Brekke, Luigi Siciliani and Odd Rune Straume, Hospital Competition and Quality with Regulated Prices, April 2009

2636 Peter Diamond, Taxes and Pensions, April 2009

2637 Shoshana Grossbard, How "Chicagoan” are Gary Becker's Economic Models of Marriage?, May 2009

2638 Roland Strausz, Regulatory Risk under Optimal Incentive Regulation, May 2009

2639 Holger Zemanek, Ansgar Belke and Gunther Schnabl, Current Account Imbalances and Structural Adjustment in the Euro Area: How to Rebalance Competitiveness, May 2009

2640 Harald Hau and Marcel Thum, Subprime Crisis and Board (In-)Competence: Private vs. Public Banks in Germany, May 2009

2641 Martin Halla, Mario Lackner and Friedrich G. Schneider, An Empirical Analysis of the Dynamics of the Welfare State: The Case of Benefit Morale, May 2009

2642 Balázs Égert, Infrastructure Investment in Network Industries: The Role of Incentive Regulation and Regulatory Independence, May 2009

2643 Christian Gollier, Expected Net Present Value, Expected Net Future Value, and the Ramsey Rule, May 2009

2644 Sören Blomquist and Håkan Selin, Hourly Wage Rate and Taxable Labor Income Responsiveness to Changes in Marginal Tax Rates, May 2009

2645 Dominique Demougin, Oliver Fabel and Christian Thomann, Implicit vs. Explicit Incentives: Theory and a Case Study, May 2009

2646 Francesco C. Billari and Vincenzo Galasso, What Explains Fertility? Evidence from Italian Pension Reforms, May 2009 